\title{
AZ ESZTERGOMI VÁR HÁROM, 1686 UTÁN KÉSZÜLT KÁLYHÁJA
}

\author{
KocSIS EDIT*
}

\section{Boldizsár Péter emlékére}

\begin{abstract}
A tanulmány az esztergomi vár három kályháját mutatja be. Mindhárom a vár 1686. évi keresztény visszafoglalását követô időszakból származik, külföldi, magas technikai színvonalon dolgozó mesterek terméke.
\end{abstract}

Kulcsszavak: kétfejü sasos csempék, I. Lipót császár, Habsburg-címer, Szent György, Esztergom

Described and discussed here are three ceramic stoves from Esztergom Castle, all made during the period after the recapture of the castle from the Turks by the Christian forces in 1686. All three ceramic stoves were made by highly skilled foreign stove-builders.

Keywords: tiles with double-headed eagles, Emperor Leopold I, Habsburg coat-of-arms, St. George

\section{Bevezetés}

A tanulmány az Esztergomi Vármúzeum kora újkori kályhacsempe-gyújteményének Lepold Antal kanonok által 1934-38 között, az esztergomi várhegy déli részén feltárt töredékeiból mutat be egy újabb csoportot. A csempedarabok annak idején rétegtani megfigyelések nélkül kerültek felszínre, így ma már csak készítéstechnikai és stíluskritikai jellegzetességek alapján, illetve az ismert analógiákat felhasználva értékelhetók. A kályhacsempéket 2010-ben az esztergomi vár középkori csempeanyagát feldolgozó és közreadó Boldizsár Péter ${ }^{1}$ bocsátotta a rendelkezésemre. ${ }^{2}$

$\mathrm{Az}$ alább bemutatott három kályha elemei a vár törököktől való végső visszafoglalása, 1686

Kézirat beérkezett: 2019. április 10.

* Kocsis Edit: Magyar Nemzeti Múzeum Mátyás Király Múzeum, H-2025 Visegrád, Fő u. 23.: e-mail: n.kocsisedit@ gmail.com

1 A cikkben közölt rajzok egy részét még Boldizsár Péter készítette el, a munkát azonban már nem tudta befejezni. Így a további szükséges rajzok Molnár Éva, Rosta Péter és saját magam munkái.

2 Az esztergomi vár kályhaanyagából korábban már közöltem egy cikket, amely a vár legkvalitásosabb, 16 . század végi kályháját mutatta be, a csempéken Jézus életéből vett jelenetekkel. Kocsis 2013, 345-366. után készültek, valószínúleg a várba beszállásolt Habsburg-katonaság tisztjei, parancsnoka számára. Mindhárom kályha feltehetően külföldi mester által, magas minőségben, jól megkomponálva elkészített fútőberendezés volt. Bár a legtöbb csempe rajzolata, plasztikája töredékes, jól érzékelhetó a gondosság az előlapok kidolgozásában, a kályhákhoz tartozó párkányok és párták kiválasztásában, így viszonylag teljes képet kaphatunk az egykori fütőberendezések felépítéséról is.

\section{Kályha osztott címerrel és kétfejü sassal}

Ennek a kályhának a csempéit homokkal finoman soványított, piszkosfehérre, olykor sárgásfehérre égett agyagból formázták. Az előlapokat élénk fúzöld vagy kissé halványabb árnyalatú zöld máz borítja. A világos cserépszín miatt a máz alatt engóbbevonatot nem használtak. Egyes darabokon a máz a földben enyhén irizálttá vált. A csempék vékony előlapját textil alkalmazása nélkül préselték a negatívokba, és a hátoldalakat szépen elsimították. Az előlapokon nagyon pontosan megkomponált, igen aprólékosan kirajzolt és finom részletességgel kifaragott minta látható. A csempék kerete többszörösen tagolt. Jellemző, hogy a képmező ábrázolásának egyes elemei 


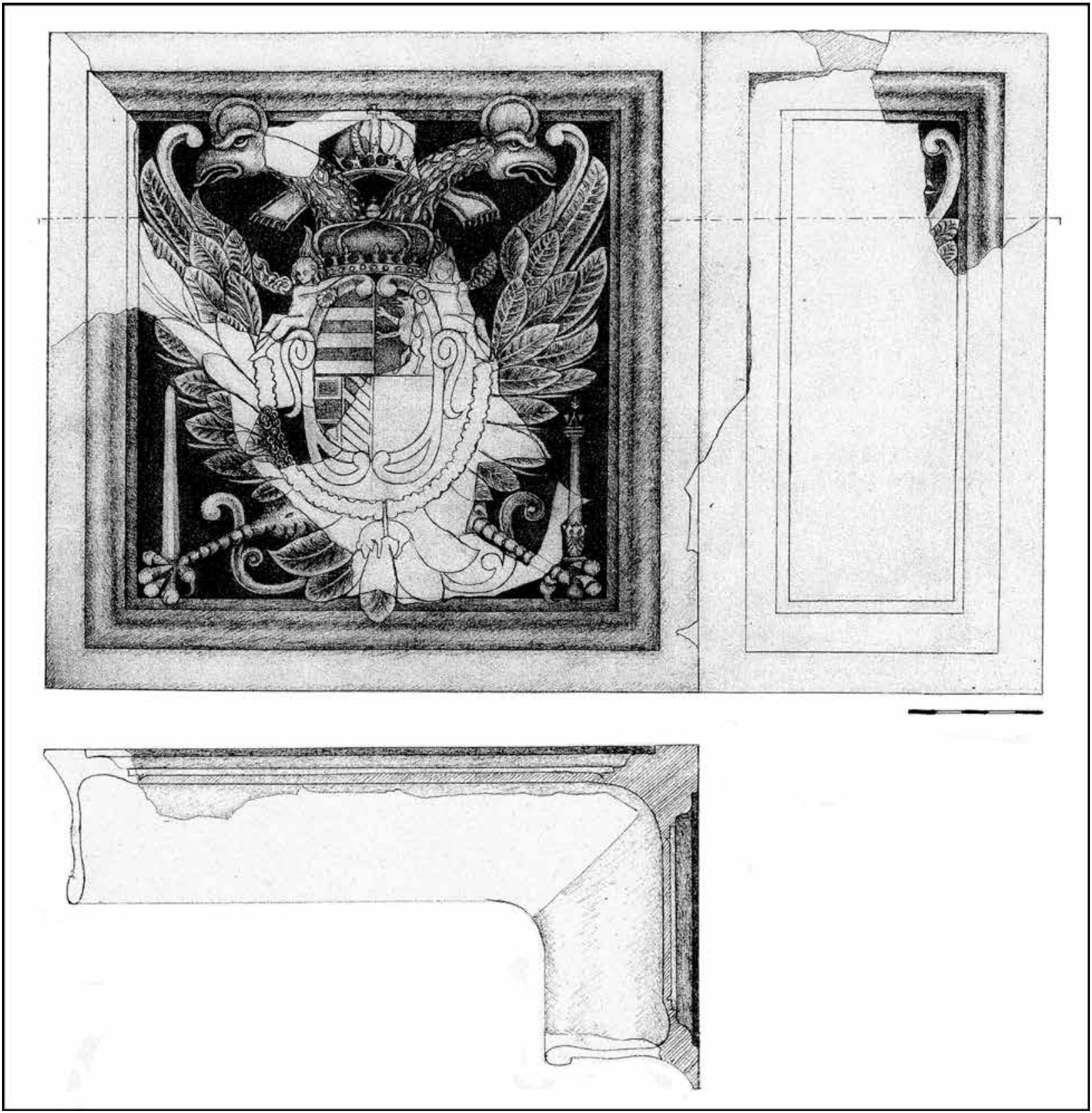

1. kép. Kályha kétfejú sassal és osztott címerrel. Sarokcsempe rajza és alulnézete négyzetes csempével és félcsempével a kályháról (rajz: Boldizsár Péter)

Fig. 1. Ceramic stove with double-headed eagle and coat-of-arms with divided field. Drawing and bottom view of a corner tile with a square tile and half-tile (drawing: Péter Boldizsár)

ráhúzódnak a keret belső részére. A préselőnegatívok tehát nemcsak a csempetükör ábrázolását tartalmazták, hanem az összetett keret is hozzátartozott. A csempéket rövid, kb. 4-6 cm mély, szalagszerû́ hátrésszel látták el, a hátrészek végét kifelé visszagyứrték, szögletesen vagy kissé lekerekítve megvastagították.

Négyzetes csempék. A négyzetes csempék átlagos magassága $25,5 \mathrm{~cm}$, szélességük $24,5 \mathrm{~cm}$. A csempék mélysége 4-6 cm között változik.
Legalább nyolc csempéből maradt fenn töredék, de ennél több is lehet, mert egyes, a csempe közepére eső darabokról nehéz eldönteni, hogy a négyzetes vagy a téglalap alakú változathoz tartoztak-e.

A csempék tagolt kerete kívül széles lemeztaggal indul, majd két finom hornyolat között a keret egy széles hengertaggal mélyül, legbelül pedig még két vékony pálca is tagolja. A képmezőt egy mellkasán címert hordozó kétfejú sas 
ábrázolása tölti ki teljesen, a két glória, a császári korona felső keresztje és a leghosszabb faroktoll még a tagolt keretre is ráhúzódnak. Az ábrázolás nemcsak finoman és részletesen kidolgozott, hanem címertanilag is pontosan kimunkált és minden részletében helytálló. Az ovális pajzs nyolcfelé van osztva. A címer 1 . negyedében a magyar vágások, a 2. negyedben Csehország ágaskodó oroszlánja látható. A 3. negyed kétfelé osztott: a heraldikai jobb oldalon Ausztria pólyás címere, baloldalt Burgundia harántpólyái helyezkednek el. A 4. negyed már négyfelé van osztva: az 1. és 4. részben a Kasztíliát jelképező tornyos vár van (az eredeti három torony helyett - a hely szúkössége miatt - csak egy torony látható), a 2. részben egy kiterjesztett szárnyú sas fedezhetó fel - ez lehet Szilézia vagy Morvaország, esetleg Tirol címere, ${ }^{3}$ míg a 3 . részben egy oroszlán ágaskodik Leont jelképezve. Az ovális pajzsot barokkos szalagkeret övezi, felső részénél egy-egy félig kifelé forduló szárnyas puttó ül, és emeli a címer fölé a császári koronát. A puttók lábaitól kettős csiholókból álló lánc indul, amely alulról és oldalról öleli körül a címert - a lánc alján az Aranygyapjas Rend jelvénye függ (1. kép bal oldala).

A szépen kidolgozott tollazatú, kiterjesztett szárnyú, szétvetett lábú sas jobb lábában függőlegesen álló pallost, bal lábában mívesen kidolgozott jogart szorongat. E két címerelem érmeken már Rudolf császár (1576-1608) idejében megjelent, s II. Mátyás (1608-1619) pénzein már a sas szorongatja a karmai között őket. A sas mindkét feje fölött glória látható, és a két nyak fölötti részen egy újabb pántos, zárt császári korona lebeg, tetején a kereszt már rányúlik a keretre, míg a korona alsó pántja alól, a sasok nyaka mögött egy-egy stóla csüng. Ez a magyarországi kályhacsempeanyagban páratlanul aprólékos és részletes címerábrázolás szinte teljesen pontosan megfelel I. Lipót császár (1657-1705) középcímerének.

Sarokcsempék. A sarokcsempék magassága $25,5 \mathrm{~cm}$, az egész csempeoldal szélessége is $\mathrm{kb}$. $25 \mathrm{~cm}$, míg a félcsempeoldal szélessége 12,9$13 \mathrm{~cm}$. Négy sarokcsempe töredéke és egy félcsempeoldali darab maradt meg.

A sarokcsempék egész csempeoldalán a fent leírt kétfejú sasos négyzetes csempe helyezkedik el, amíg a félcsempeoldalon egy felezett méretú, ugyancsak kétfejû sasos csempe foglal helyet, ez utóbbi azonban nem a négyzetes típus ketté-

3 Ez a címerelem olyan apró, hogy megkülönböztetó jegyeket már nem lehetett rajtuk agyagból megformálni, illetve a csempén sajnos a színek sem látszanak. vágásával jött létre, hanem egy külön negatívot készítettek hozzá, amely - részletformái szerint azonos faragó munkájának túnik. Sajnos a félcsempe teljes rajzolatát nem ismerjük, de a megmaradt részletek alapján a fent leírthoz hasonló, négyzetes, kétfejú sasos csempe kettémetszésével jött létre (ugyanis a megmaradt tollrészletek mind a négyzetes, mind a téglalap alakú típustól eltérnek). A sarokcsempék sarokéle derékszögú kiképzésú, a két csempe keretét egyszerúen összeillesztették (1. kép).

Téglalap alakú csempék. A téglalap alakú csempék magassága $30,3-30,5 \mathrm{~cm}$, szélessége $21 \mathrm{~cm}$, a hátrész mélysége 4-6 $\mathrm{cm}$. Legalább 18 csempe töredéke van meg.

A csempék ábrázolása majdnem azonos a négyzetes darabokéval, de egyes részletek - már csak a nyújtottabb csempeforma miatt is - eltérnek attól. Láthatóan törekedtek a négyzetes képmezőbe szerkesztett képet téglalap alakba átszerkeszteni, s a sas teste és más elemek is nyújtottabbak lettek. A csempék kerete ugyanannyira tagolt, mint a négyzetes formánál, de itt a hengertag helyett egy széles, homorú elemmel mélyül a csempe, s belül sem két vékony pálcával, csak két keskeny lépcsővel végződik a keret. A magasabb képmezó miatt a sasok glóriái a kereten belülre kerültek, felül a korona keresztje, alul pedig a dús faroktollazat középső tollának vége takarja, a keskenyebb rendelkezésre álló hely miatt a szárnytollak végei pedig rendre az oldalkeretre simulnak. Eltérés még, hogy míg a négyzetes darabokon a címerkoronát tartó szárnyas puttók félig kifelé fordulnak, mintegy rajta ülnek a szalagkeret végső kacskaringóján, addig a téglalap alakú csempéknél a két puttó teljesen a címer és a korona felé fordul (2-3. kép).

Középpárkány. Fektetett téglalap alakú, ívelt, felfelé szúkülő falú párkánycsempe, viszonylag vékony falú. Magassága $13 \mathrm{~cm}$, szélessége $29,5 \mathrm{~cm}$, mélysége kb. $8 \mathrm{~cm}$. Hét csempéhez tartozó töredékek.

A párkány alsó, felfelé ívelten szúkülő harmadában - széles léctag és lépcső felett - lefelé fordított levélsor fut szépen tagolt szélú levelekkel. A levelek alól apró bemélyedésekkel poncolt háttér kandikál ki. A középső, függőleges falú harmadban a széleken ládaveretekre emlékeztetó motívum látható, majd beljebb egy-egy oroszlánfejre hasonlító maszk. A maszkokat a másik oldalról is a veretszerú motívum fogja közre. A sáv közepén még egy díszítóelemnek kellett lennie, s ez valószínúleg egy kagyló lehetett, de ebből sajnos nem maradt fenn töredék. A kagylómotívum meglétére csupán a leszabott párkánydarabok jobb szélén megmaradt kis kagylórészlet utal. 


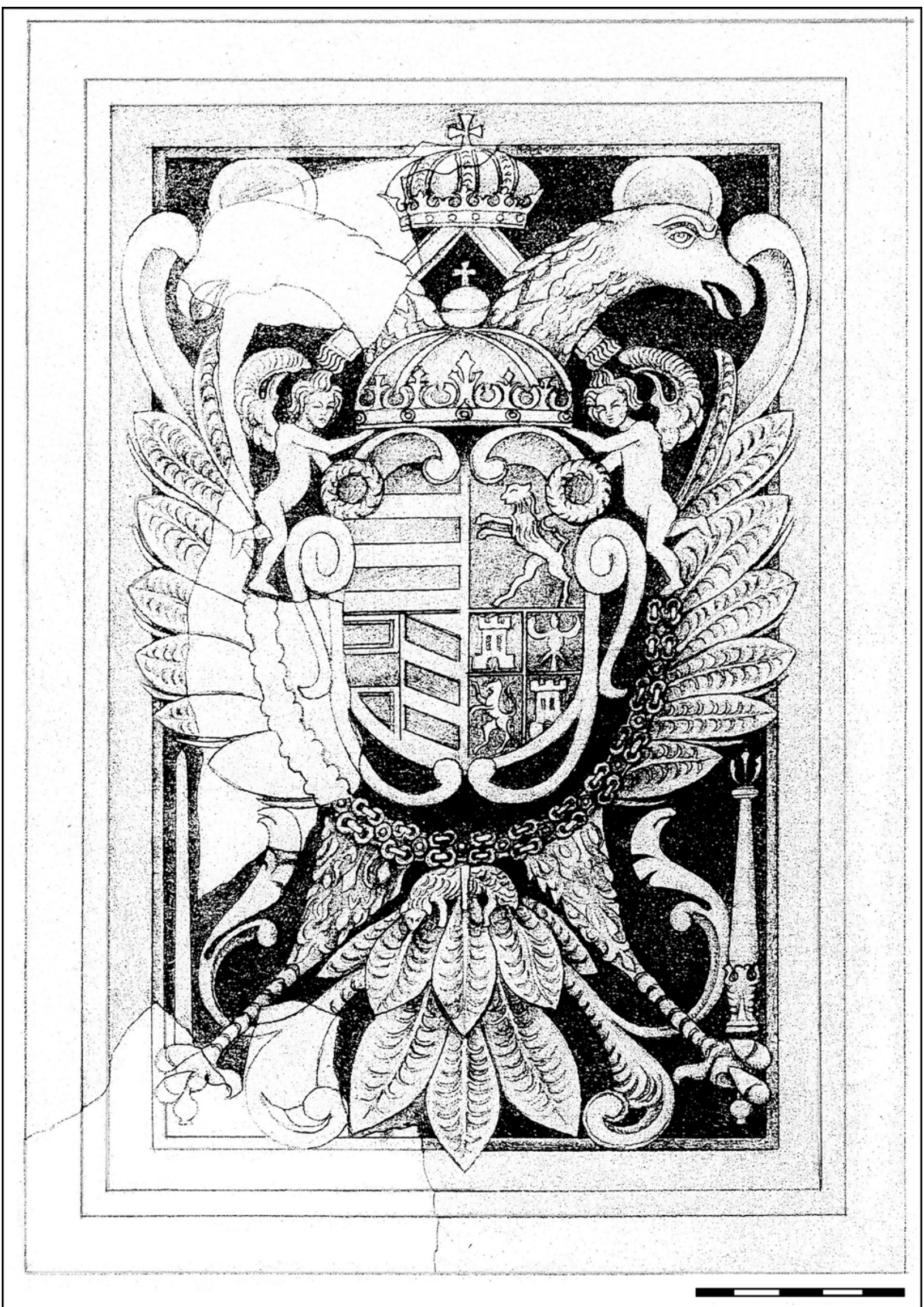

2. kép. Kályha kétfejű sassal és osztott címerrel. Téglalap alakú csempe rajza a kályháról (rajz: Boldizsár Péter)

Fig. 2. Ceramic stove with double-headed eagle and coat-of-arms with divided field. Rectangular tile (drawing: Péter Boldizsár) 


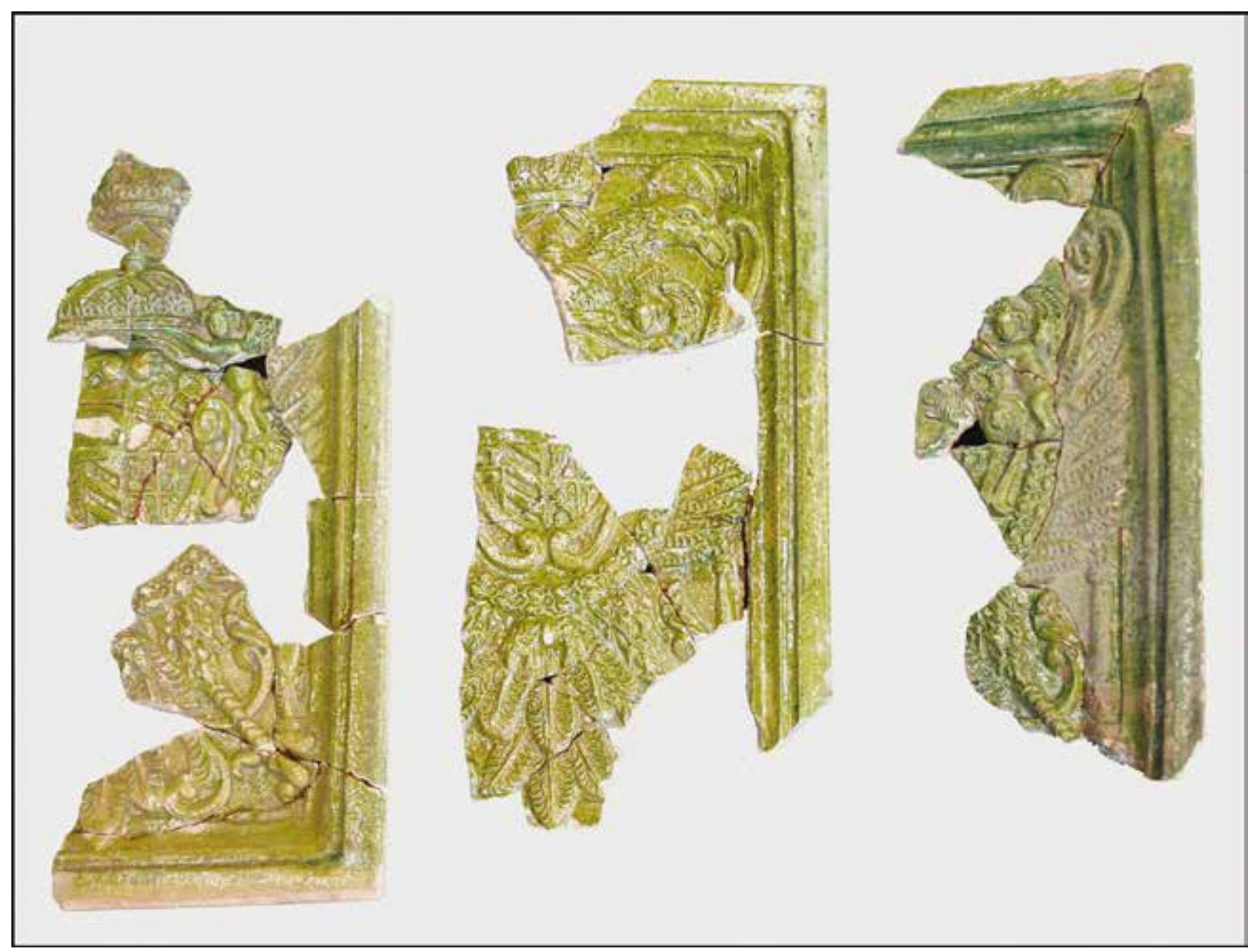

3. kép. Kályha kétfejű sassal és osztott címerrel. Téglalap alakú csempék töredékei (fotó: Kocsis Edit)

Fig. 3. Ceramic stove with double-headed eagle and coat-of-arms with divided field. Fragments of rectangular tiles (photo: Edit Kocsis)

A párkánycsempe felső sávja ismét kissé előreugrik, ezt a részt két lépcső és egy szélesebb borda tagolja (4. kép 1). ${ }^{4}$

Koronázó párkány. Felfelé szélesedő trapéz alakú, ívelt, felfelé erősen kihajló falú párkánycsempe. A csempe magassága kb. 13-14 cm lehet, felső szélessége $22,2 \mathrm{~cm}$, alsó szélessége kb. $20 \mathrm{~cm}$ lehet, mélysége 5,5-10 cm. Három példányból vannak töredékek.

A felfelé szélesedő párkány alsó részét egy nagy, kiugró borda tagolja, a felette levő függőleges állású sáv díszítéséről csak annyit tudunk, hogy kör alakban bemélyedő mintasor is van rajta. Az ívelten kihajló, széles felső sávot plasztikus, erősen tagolt levélszélú, stilizált levélsor

4 Az itt bemutatott párkányhoz hasonló darab került elő egy 1710 körülre keltezhető rétegbőll a szolnoki vár 2018. évi ásatásán is. Kertész Róbert szíves közlése, akinek az adatot ezúton is köszönöm. díszíti. Felül széles, függóleges léctag zárja le a párkányt (4. kép 2). ${ }^{5}$

Párta. Ívelt kivágású párta, háta alján teljes szélességében végigfutó, ívelt hátsó támasztékkal. Magassága kb. $19 \mathrm{~cm}$, szélessége 24,4 cm, mélysége $4,4 \mathrm{~cm}$. Öt pártából maradtak fenn töredékek.

$\mathrm{Az}$ alul végigfutó keskeny léctag felett a párta közepén egy nagyjából ovális (alul kissé jobban összeszúkülő) keretben kiterjesztett szárnyú és lábú birodalmi kétfejú sas látható. A sasok fején glória van, kétfelé ívelődő nyakuk felett nyitott, ötleveles korona helyezkedik el. A keretbe foglalt sast különböző irányba tekeredő, kacskaringós, széles, leveles indák ölelik körül, némelyik a keretre is rálóg. A párta csúcsán az indákból tobozszerú díszítmény nó ki. Az indák és a toboz mentén körbevágott párta erősen tagolt szélú, barokkosan mozgalmas képet nyújt. Az indák, de fóleg

5 Boldizsár Péter utolsó, nem teljesen befejezett rajza. 

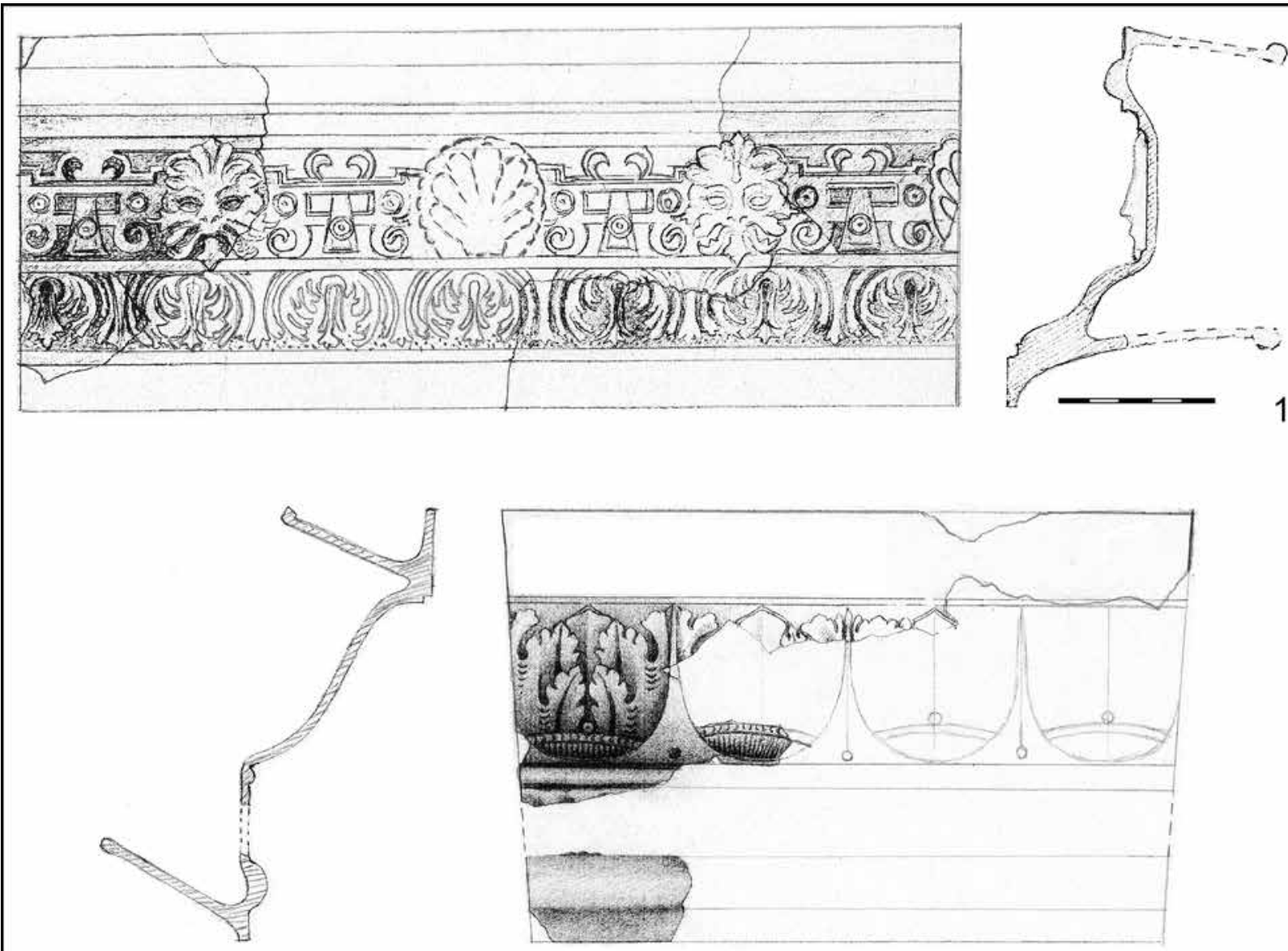

4. kép. Kályha kétfejú sassal és osztott címerrel. 1: Középpárkány rajza és metszete; 2: Koronázó párkány rajza és metszete (rajz: Boldizsár Péter)

Fig. 4. Ceramic stove with double-headed eagle and coat-of-arms with divided field. 1: Drawing and section of the cornice above the lower stage; 2 . drawing and section of the cornice above the upper stage (drawing: Péter Boldizsár)

a kétfejú sas és a toboz kidolgozása igen aprólékos, finom, vékony vonalakkal megoldott munka (5. kép 1-2).

\section{A kályha felépitése}

A kályhához tartozó lábazati párkány eddig nem került elő, lehet, hogy ilyen nem is tartozott a kályhához. A fútőberendezés alsó, túztér körüli része a szokásos módon, négyzetes csempékből épült fel. A sarkokon egész és felezett méretú csempékből összeépített sarokelemeket alkalmaztak, és a sorokat félcsempényivel eltolva, kötésben helyezték egymás fölé. A vállrészen vékony, díszes középpárkány húzódott, ez a sor vezetett át a téglalap alakú csempékből rakott toronyhoz, amely sokszög alaprajzú lehetett. A kályha tetejét kihajló koronázó párkány és azon álló, barokkosan mozgalmas szegélyú pártasor zárta le.

\section{A kályhát készítő mühely}

A szépen kidolgozott, pontosan megkomponált csempéket külföldi - az alapos címertani ismeretek alapján talán a Habsburg Birodalom örökös tartományai területéről származó - múhely készíthette. Erre mutat a csempék heraldikailag minden elemében pontos és páratlanul részletes kidolgozottsága, valamint a préselőnegatívok finom kimunkáltsága, és az a Magyarországon szokatlan jellegzetesség, hogy az elólap úgy van megkomponálva, hogy egyes elemei rendre rányúlnak az összetett keretre. Magyarországról eddig még nem került elő sem heraldikai programjában ennyire gondosan kivitelezett, sem plasztikai megoldásaiban ilyen kifinomultan kialakított csempéjú kályha a korszakból.

A 17. század végi felszabadító harcok során a törököktől visszafoglalt várak, erődök egy részé- 


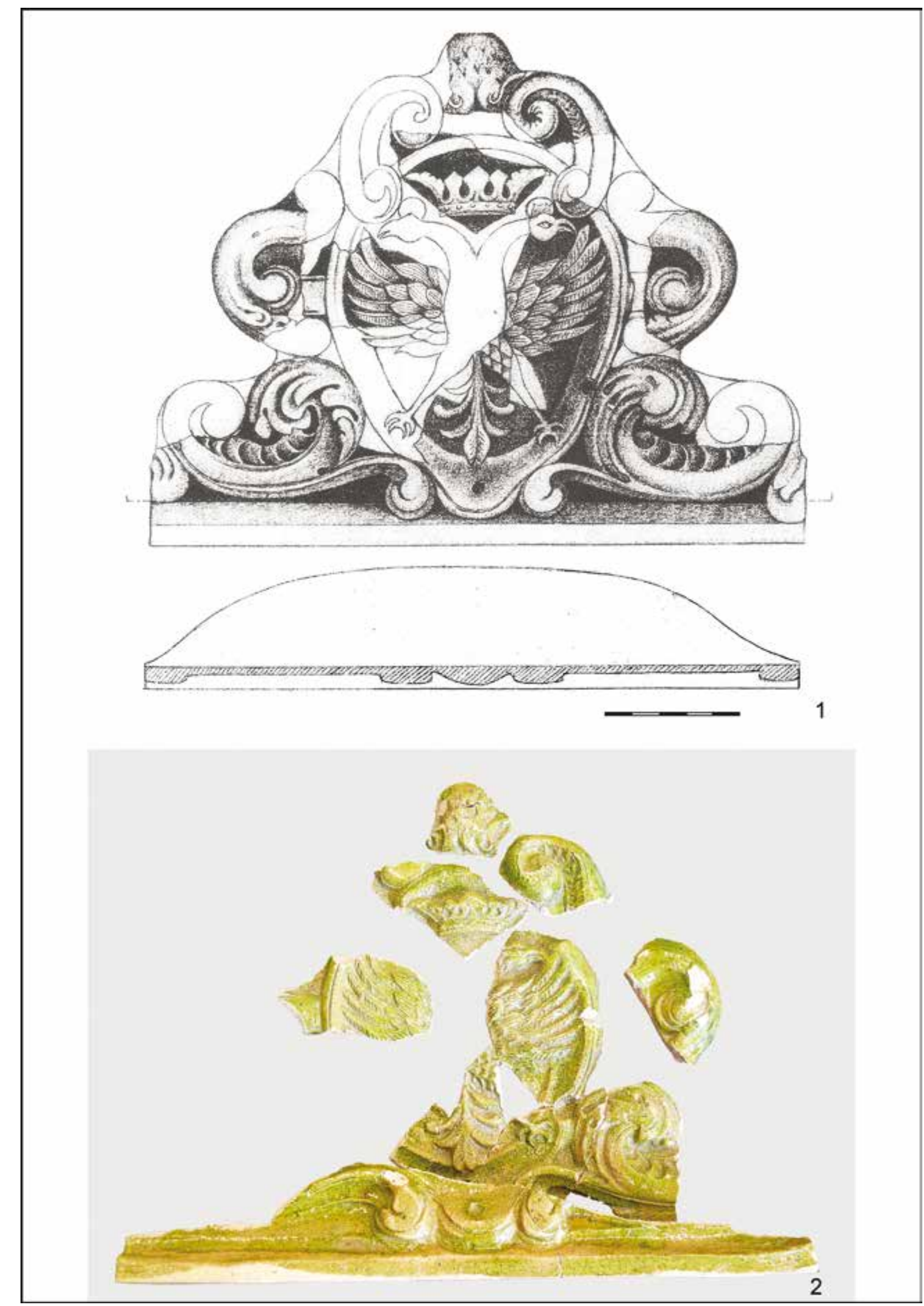

5. kép. Kályha kétfejú sassal és osztott címerrel. 1: Pártalap rajza és metszete; 2: Pártalap töredékei (rajz: Boldizsár Péter, fotó: Kocsis Edit)

Fig. 5. Ceramic stove with double-headed eagle and coat-of-arms with divided field. 1: Drawing and section of a crest tile; 2: fragments of a crest tile (drawing: Péter Boldizsár, photo: Edit Kocsis) 
be Habsburg-katonaságot szállásoltak be. Ezzel függhet össze, hogy a katonák és tisztjeik kényelmére helyreállított, a birodalmi kincstár által berendezett épületekbe nagy számban gyártottak olyan kályhákat, amelyeken a fó díszítóelem a birodalmi kétfejú sas volt. A kincstár szívesen rendelhette meg ezt a motívumot, akár népszerúsító célzattal is.

Korábban sem voltak ismeretlenek a kétfejú sassal díszített csempék Magyarországon. A motívum gyakran előfordult a Habsburg-kézen maradt magyar területek kályháin is (Sümeg6). Különösen sokféle kétfejú sasos csempeváltozat került elő a Habsburg-katonaság által megszállt erősségekből (Eger, ${ }^{7}$ Szendrő, ${ }^{8}$ Esztergom, Vác, ${ }^{9}$ Buda $^{10}$ ) vagy azok közeléből (Óbuda ${ }^{11}$ ). Ugyanakkor - ahogy erre Tomka Gábor is felhívta a figyelmet $^{12}$ - a magánbirtokosok kezén levő várakban már korántsem jellemző az ilyen díszítőmotívumú kályhacsempék megléte (Ónod, Diósgyőr, Sárospatak, Füzér, Pácin, Kéked).

A kétfejú sast ábrázoló csempék igen változatos negatívokkal készültek, jobb minőségú vagy egészen gyenge kivitelben. Általánosan jellemző rájuk, hogy csak bizonyos heraldikai elemek jelentek meg rajtuk: a glória, a császári korona, a stóla, egyes darabokon a sas lábaiban szorongatott pallos és a jogar. A sas mellén fekvő címerpajzs többnyire csak kétfelé volt osztva. Rajta vagy csak a legegyszerúbben ábrázolható osztrák-burgundi címer volt látható, vagy a magyar címer valamelyik eleme. (Sőt, teljesen félreértett, imitált címerre is van példa. $\left.{ }^{13}\right) \mathrm{Az}$ Aranygyapjas Rend jelvénye nem szokott megjelenni ezeken a darabokon, sem puttók, akik a címerkoronát tartják. A kályhacsempék többségét minden valószínúség szerint magyarországi, helyi (városi vagy mezóvárosi) múhelyekkel gyártatták le, ezért ezek a darabok megfeleltek a hazai csempekészítési technika jellegzetességeinek. Rendre egyszerú keretekkel készültek, s rajtuk a Habsburgcímerelemeknek csak a legfontosabb jellemzóit ábrázolták, sokszor népies ízú díszítőelemekkel kiegészítve. Ezek a hazai múhelyek által készített csempék terjeszthették el a kétfejú sasos motívumot, amely még a 18. században is sokáig nép-

\footnotetext{
KOZÁK 1963, 168-174.

KozÁK 1963, 175-179.

TOMKA 2011, 585-597.

SÖMJÉNI 2014, 132-137.

KoZÁK 1963, 167-168.

JuHÁSz 1999, 361-364.

2 TOMKA 2011, 595.

3 2017-ben Buzás Gergelynek az egri várban folytatott ásatásai során is került napvilágra ilyen imitált címerrel ellátott, mázatlan csempe.
}

szerû maradt, idővel szinte népies díszítőelemmé torzult.

Az esztergomi osztott címeres kétfejú sasos kályhát gyártó múhely kivételt jelent az eddig ismertté vált kétfejű sasos csempék között. Sajnos azonban nem ismerjük elég jól a korszak ilyen típusú csempéit, mert még a felszínre került darabok közül is igen kevés van publikálva. Mégis az a valószínúbb, hogy ezt a kályhát nem hazai múhelytől rendelték meg. Ebben szerepet játszhatott az is, hogy Esztergom jóval közelebb feküdt az örökös tartományokhoz, s a Duna vízi útján könnyen és olcsón eljuthattak ide akár a kályhacsempék, akár maga a kályhásmester is.

\section{Lipót császár portréjával és kétfejú sassal díszített kályha}

A kályha csempéit homokkal erősen soványított, világosdrapp színúre égetett cserép jellemzi. Az előlapokra - vékony fehér engóbréteg fölé - világosabb, vagy néha sötétebb árnyalatú, fakózöld máz került. Néhány darabon ez az egyenetlen, híg máz foltosra - szinte világoszöld alapon sötétzöld pettyesre - sikerült. Egyes négyzetes csempéket, valamint a párták egy részét zsákvászonszerú anyag segítségével préselték a negatívba, más ugyanolyan darabokat azonban nem. A téglalap alakú csempéken és a párkánydarabon egyáltalán nincs textillenyomat, itt inkább a mélyebb részeknél ujjal nyomkodták be az agyagot a formába, egyes csempék hátoldalát viszont szépen elsimították. Jellegzetes díszítőmotívum a kereteknél, illetve a párkánycsempénél a bordakötegek, illetve lépcsők keresztirányú redőzése, "szaggatottá tétele". Az előlapokon nagy plasztikai különbségek figyelhetők meg. Az ábrázolás egyes elemei aprólékosan részletezettek és kidolgozottak, ugyanakkor az összképet tekintve a negatívok rajzolata mégis jóval elnagyoltabb és pontatlanabb, mint az osztott címeres kétfejú sasos csempék esetében. Az egyes darabok elkészítése sem mindig olyan gondos munka: több csempén is láthatjuk, hogy az előlapok bizonyos részletei elnyomódtak. A csempék kerete többszörösen tagolt, $\mathrm{s}$ a négyzetes csempéknél itt is jellemző, hogy a császári korona glóbusza és keresztje, illetve a leghosszabb faroktoll vége felül és alul ráhúzódik a keretre. A préselőnegatívok tehát nemcsak a csempetükör ábrázolását, hanem az összetett keretet is tartalmazták. A csempéket rövid, kb. 5-6,5 cm mély, szalagszerú hátrésszel látták el, a hátrészek végét pedig ugyancsak jellegzetes módon, kifelé háromszög alakban kidudorodva alakították ki. 


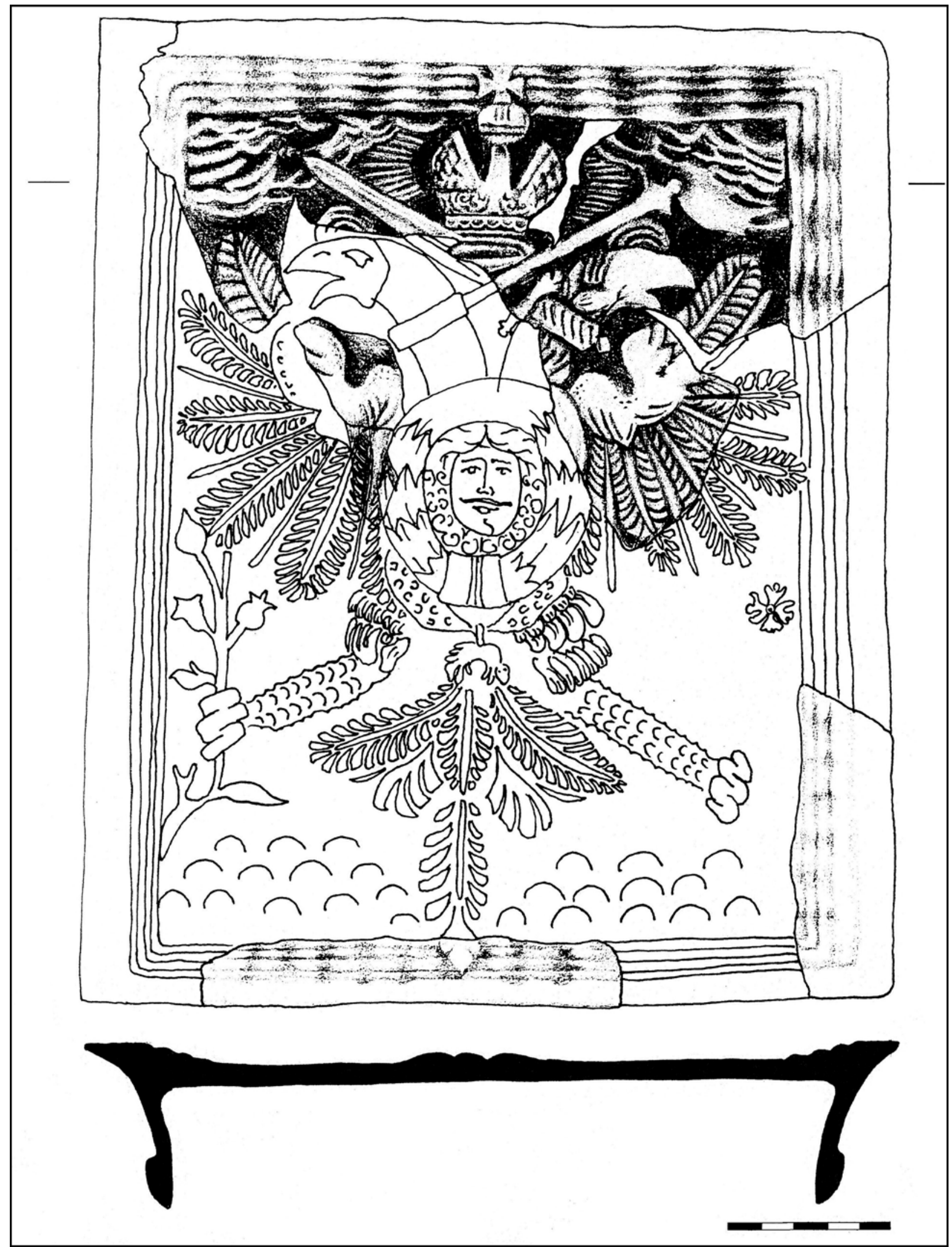

6. kép. Kályha kétfejú sassal és I. Lipót császár portréjával. Négyzetes csempe rajza és metszete (rajz: Rosta Péter) Fig. 6. Ceramic stove with double-headed eagle and portrait of Emperor Leopold I. Drawing and section of a square tile (drawing: Péter Rosta) 
Négyzetes csempék kétfejü sassal. A csempék valószínú magassága $\mathrm{kb}$. $25-26 \mathrm{~cm}$, szélességük kb. $25 \mathrm{~cm}$, mélységük 5-6 cm. Öt csempe töredékeit ismerjük.

A csempék összetett kerete széles léctaggal indul, amelyet egy bemélyített vonal választ el a mélyülő résztől. Ez a léctag alul és felül keskenyebb, mintegy $1 \mathrm{~cm}$-es, kétoldalt viszont 1,3$1,5 \mathrm{~cm}$ szélességú. A keret belső része a bemélyített vonaltól három keskeny lépcsőben mélyül a képmezőig. A hármas lépcsőt viszont körben, egymástól kb. 1,5 cm-nyire kialakított keresztirányú befaragásokkal mintegy "szaggatottá” tették. Így igen jellegzetes keretet hoztak létre a képmező körül. A keret szaggatott, lépcsős részére ráhúzódik még felül a császári korona glóbuszának felső része és a kereszt, alul pedig a sas középső faroktolla.

A képmezőt szinte teljesen kitölti az ábrázolás: a kiterjesztett szárnyú és lábú, kétfejú sas. A sas hasán - a megszokott címerpajzs helyett - alul abronccsal átfogott babérkoszorú van, amelyben I. Lipót császár hosszú parókás, bajuszos, jól ismert arcképét láthatjuk szemból ábrázolva. Szokatlan módon a sas két nyakán keresztben átvetve jelenik meg a hatalmi jelvényként ábrázolt pallos és jogar. A tárgyak markolata a sasok nyakán húzódik keresztül. A pallos esetében liliomos végú keresztvasat, ferdén áttekert markolatot és kerekded markolatgombot figyelhetünk meg, a jogar markolata sajnos nem maradt meg. A jelvények középen keresztezik egymást, és végük, vagyis a kard hegye és a jogar liliomos vége a sasok glóriája fölött végződik. Közvetlenül a kereszteződésük felett lebeg a császári korona, amely az ábrázolás legplasztikusabb része, és finom vonalak rajzolják ki részletformáit: az ékkôsorral díszített pántot, a leveleket és azt a vékony, hálószerú anyagot, amely a felső pántok között feszül. A korona tetejét nagy, tagolt glóbusz díszíti egyenlő szárú kereszttel, ezek a részek már a felső keretre simulnak rá. $\mathrm{S}$ mintha még ezzel is ki akarták volna emelni a korona jelentóségét, két oldalán finoman bevésett sugárnyalábok indulnak, mintha a korona a nap szerepét töltené be, belőle áradna a fény. A képmező felső sarkain pedig - barokk festményeket utánozva - felhőket imitáló redőzet tölti ki a teret (7. kép 1). A képmező alsó részéból kevésbé maradtak fenn töredékek, így ezt a részt a téglalap alakú csempék analógiája alapján képzelhetjük el: a babérkoszorú alatt még az Aranygyapjas Rend lánca és jelvénye lógott, a sas jobb lábában egy liliomszerú szirmokkal ábrázolt mezei virágot, bal lábában egy másik, négyszirmú virágot tartott. A sas kiterjesztett faroktollai közül a leg- hosszabbnak a vége szintén rásimult az alsó keretre (6. kép).

Négyzetes csempék ismeretlen elólappal. A csempék valószínú magassága $25 \mathrm{~cm}$, szélességük $\mathrm{kb}$. $25 \mathrm{~cm}$ lehetett, mélységük 5-6 cm. Négy csempe töredékeit ismerjük.

Ugyanezzel az anyaggal és keretmegoldással kerültek még elő más töredékek is, amelyek egy vagy két további csempetípushoz tartoztak. Az egyik darab egy csempe teljes jobb oldala, amelyen a képmező felső sarkában egy befelé forduló nyakú, testéhez simuló szárnyú madár részlete látható, az alsó sarokban pedig egy leveles inda (7. kép 2). Egy másik csempe saroktöredékét nehéz értelmezni: egy glóbuszszerú forma, amelyből ferdén egy rúd indul ki. Mindkét csempetípusból olyan kevés maradt meg, hogy akár sarokcsempe félcsempéjéhez is tartozhatnak ezek a részletek.

Sarokcsempék. A sarokcsempék magassága is 25-26 cm lehetett, az egész csempeoldal szélessége valószínúleg $25 \mathrm{~cm}$ volt, a félcsempeoldalról nem ismerünk töredéket. Két csempéből van darabunk.

A két sarokcsempetöredék csak annyit árul el, hogy összeépített sarokcsempék készültek, a négyzetes oldalon a kétfejú sasos csempével. A sarokél egyszerú, szögletes megoldású volt, a két tagolt csempekeretet egyszerúen összeillesztették.

Téglalap alakú csempék. A csempék magassága kb. $28-28,5 \mathrm{~cm}$, szélességük $\mathrm{kb}$. $20 \mathrm{~cm}$, mélységük 5-6 cm. 9-11 csempe töredékei.

A csempék összetett kerete a négyzetes darabokéhoz hasonló, de jóval keskenyebb. A külső léckeret átlag $1 \mathrm{~cm}$ széles, oldalt mintegy $1 \mathrm{~mm}$ rel szélesebb, mint alul és felül. A mélyülő rész is a másikhoz hasonló kialakítású, keresztirányú befaragásokkal szaggatott, de csak két lépcsőből áll, s ebból is a felső lépcső sokszor egybenyomódott a felső léctaggal, ezért nem mindig érzékelhető.

Az előlapon egy kétfejú sas, mellén egy babérkoszorúban I. Lipót császár arcképével (9. kép), alatta az Aranygyapjas Rend jelvényével. A sas két nyakán keresztbe téve pallos és jogar látható, felettük, a felhők között - sugárkoszorúval közrefogva - lebegő császári korona van. A sas jobb lábában egy liliomszerú, leveles virágot, bal lábában egy négyszirmú virágot tart. Az ábrázolás részletformái szinte azonosak a négyzetes csempeváltozatéval, de mivel a képmezó pár cm-rel magasabb, mint a másik típusnál, alul és felül 


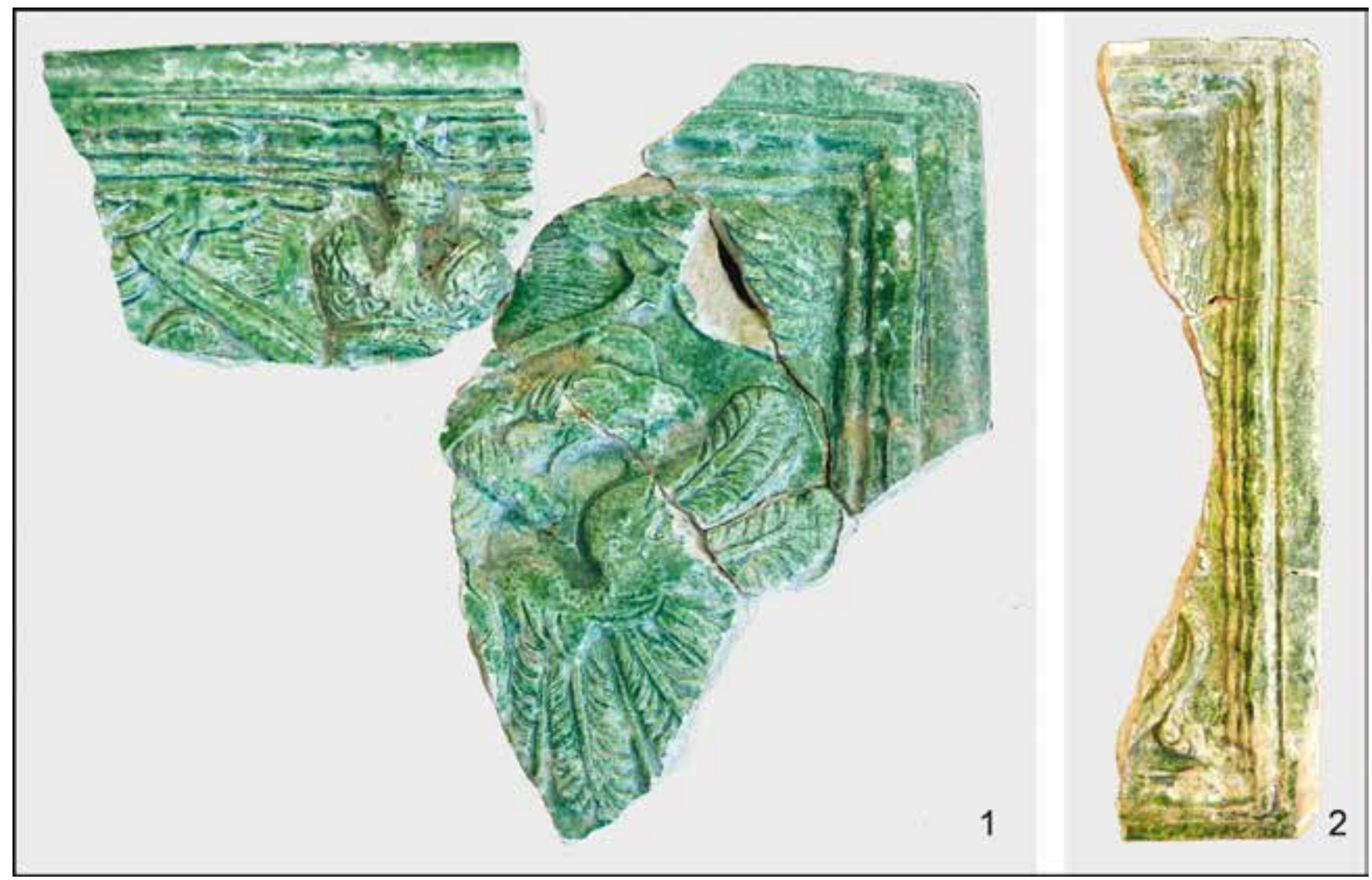

7. kép. Kályha kétfejú sassal és I. Lipót császár portréjával. 1: Négyzetes csempe töredékei; 2. Négyzetes csempe vagy félcsempe töredéke (fotó: Kocsis Edit)

Fig. 7. Ceramic stove with double-headed eagle and portrait of Emperor Leopold I. 1: Fragments of a square tile; 2. fragment of a square tile or half-tile (photo: Edit Kocsis)

2-3 cm-es sávban kissé szabálytalan, pikkelyszerú redőzet tölti ki a teret, ezért az ábrázolás sehol sem nyúlik rá a keretre (8. kép).

Középpárkány. Fektetett téglalap alakú, felfelé szúkülő vonalú középpárkány. Magassága $13 \mathrm{~cm}$, mérhető szélessége $13,9 \mathrm{~cm}$, mélysége $6,5 \mathrm{~cm}$. Csak egy csempe töredéke ismert. Fala viszonylag vékony, hátoldala alig kormos, ezért valószínúbb, hogy középpárkány, mint lábazati csempe.

Széles alsó léctag és egy vékony lépcső felett a párkány vonala "S" alakban szúkül. Az "S" alakú sávot egy alig tagolt szélú és plasztikusan is kevéssé díszített, lefelé forduló levélsor díszíti, amelyet felül is egy lépcső zár le. A párkány feljebb futó, függőleges falú sávjában három vízszintes borda látható, amelyeket 2-2,5 cm-enként függőlegesen redőztek, hasonló módon, mint a négyzetes és téglalap alakú csempék keretét. A párkány felsó sávját egy vaskos, előreugró hengertag és egy léctag zárja le (10. kép 1-2).

Párta. Hátrafelé enyhén ívelődő alaprajzú, ívelten kivágott párta, hátul végigfutó, közép felé szélesedő támasztólappal. Magassága kb.
$14,5 \mathrm{~cm}$, szélessége $28 \mathrm{~cm}$, mélysége $3 \mathrm{~cm} .9$ párta töredékei maradtak meg.

A motívum széle mentén szabálytalan ívben körülvágott párta a korszakban széles körben elterjedt, igen népszerú „delfines” párták közé tartozik. Az előlap alját egy felül ferdén lemetszett sarkú, széles léctag adja, amely elnagyolt kialakítású. A középső tengelyre nagyjából szimmetrikus előlap két oldalán egy-egy kifelé néző delfin látható, amelyek a szájukban egy-egy gömböt tartanak. A delfinek farka felülről lefelé és befelé csavarodva tölti ki a képmező nagy részét. Az összetekeredő delfinfarkak közepén egy-egy stilizált virág látható. A delfinek hátára levelek borulnak, illetve habok tornyosulnak. Ezek között egy-egy meztelen puttó lovagolja meg a delfineket. Középen, az összeérintkező delfinfarkak alól egy kis harang alakú virág lóg ki - kitöltve az üres helyet -, míg felül egy szépen tagolt, leveles glóbusz emelkedik ki, harmonikus felső lezárást adva a pártának (10. kép 3).

A kályha felépitése. A kályha felépítése igen hasonló lehetett az osztott címeres kétfejú sasos kályháéhoz. A fő témának, a kétfejú sasos, Lipót csá- 


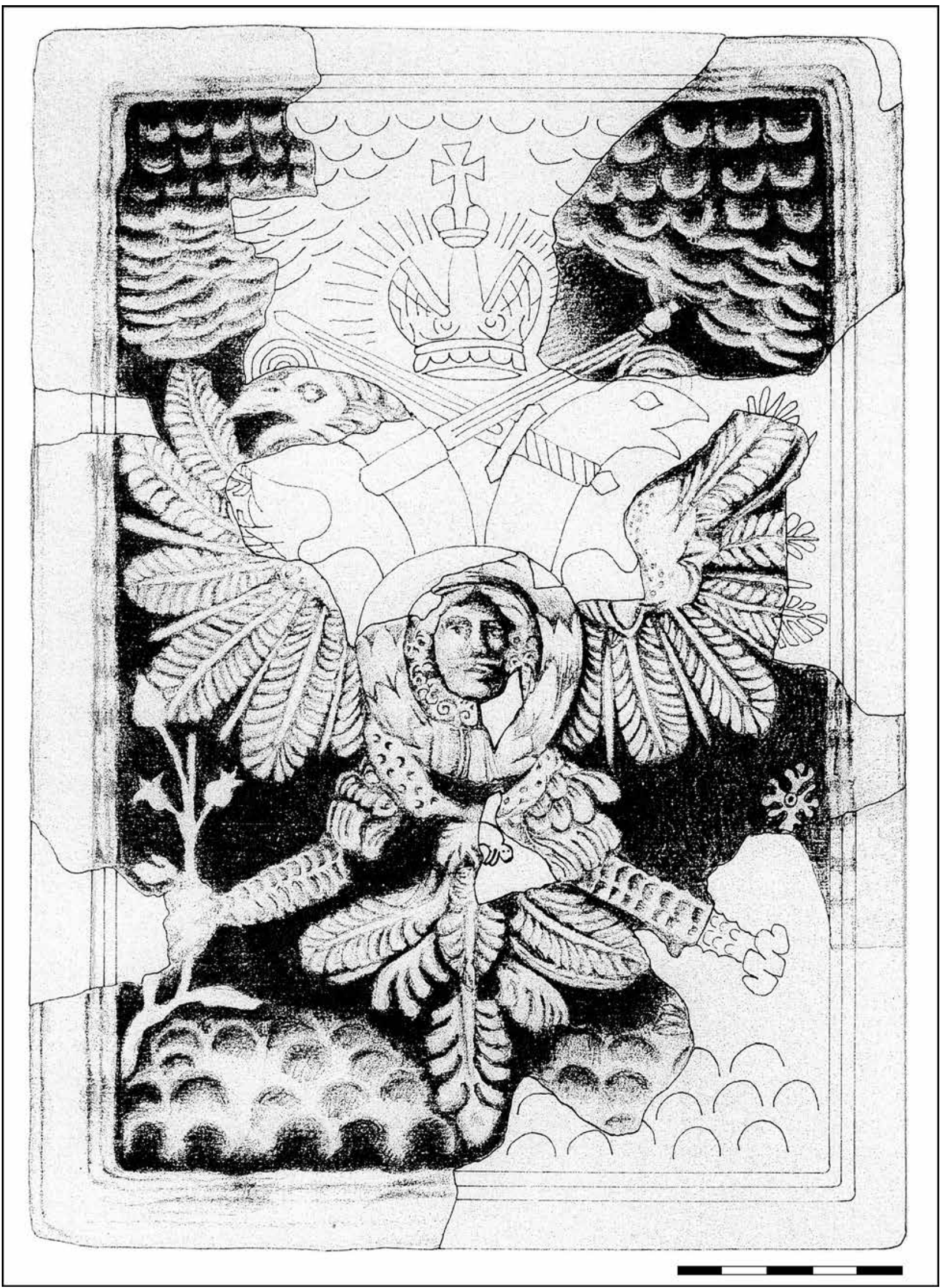

8. kép. Kályha kétfejú sassal és I. Lipót császár portréjával. Téglalap alakú csempe (rajz: Rosta Péter)

Fig. 8. Ceramic stove with double-headed eagle and portrait of Emperor Leopold I. Rectangular tile (drawing: Péter Rosta) 


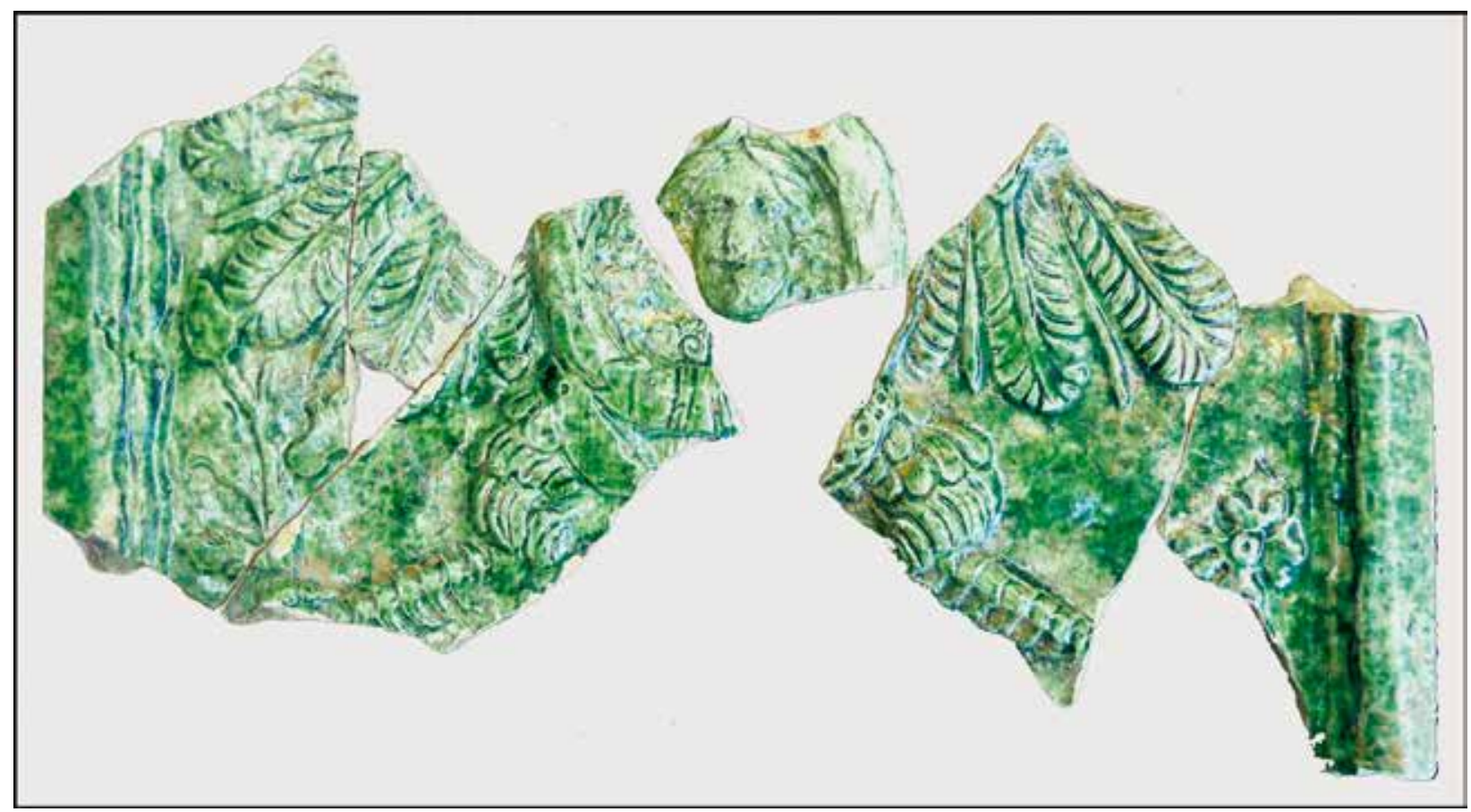

9. kép. Csempetöredékek I. Lipót császár portréjával (fotó: Kocsis Edit)

Fig. 9. Tile fragments with a portrait of Emperor Leopold I (photo: Edit Kocsis)

szárportrés csempének volt egy négyzetes és egy téglalap alakba szerkesztett variációja (ahogy ez a korszakban nem ritka), az elóbbit a kályha alsó részén kötésben, az utóbbit - sokszög alakú toronyban - a fútőberendezés felső részén helyezték el. Az alsó részen összeépített sarokcsempéket és félcsempéket is alkalmaztak. Jóval kevesebbet tudunk a párkányokról. Csupán egyetlen párkánytöredék került elő a kályha jellegzetes cserépanyagából és díszítésével. Téglalap alakja, vékony fala és hátoldalán a kormosság hiánya miatt valószínúleg középpárkány lehetett. Biztosan volt trapéz alakú, kihajló tetejú felső párkánya is a kályhának, de sajnos a leletanyagban ezt nem lehetett kétséget kizáróan megtalálni. A korban divatos és népszerú delfines párták közül azonban az egyik variáció - anyagával és az egyes darabok hátoldalán megjelenó textillenyomattal - szintén ehhez a kályhához sorolható. Ez adhatta meg a szép, ívelt vonalú felső lezárást.

\section{A kályhát készitô mühely}

A kétfejŭ sasos csempéken hangsúlyos szerepet kapott néhány jellegzetes stíluselem, amelyek párhuzam nélküliek a magyarországi csempeanyagban. Ilyen például Lipót császár képmásának megjelenése a sas mellkasán, vagy a jogarnak és a pallosnak az egymást keresztező elhe- lyezése a sas két nyakán. Ennek a kályhának az esetében még valószínúbb, hogy külföldi múhelyek között kell keresni a kályha készítőjét, de a különleges ábrázolásra tekintettel valószínúleg Habsburg-kapcsolatokkal bíró területen. S valóban, német területen került is eló néhány olyan csempe, amelyeken, ha nem is egy múhelyböl származnak, de megjelennek hasonló ábrázolás elemei. Így például Lipót császár portréja látható egy colmari múzeumban őrzött darabon, bár itt nincs ábrázolva a kétfejú sas. Ugyancsak ismeretlen lelőhelyú egy Landshutban őrzött csempe, amelyen a kétfejú sas mellkasán egy babérkoszorúban Lipót császár félprofilból ábrázolt feje tûnik fel, itt azonban a pallost és a jogart a sas lábai markolják, s a zárt császári koronát két angyal lebegteti a sas fölött. Ennek ellenére ez a darab hasonlít legjobban az esztergomi csempékre. A sas nyakán keresztben elhelyezett pallosra és jogarra is akad példa, egy szintén ismeretlen lelőhelyú, Wiesbadenben órzött csempén, s a sas mellkasán itt is egy koszorúba foglalt mellkép látható, de ezúttal nem Lipót császáré, hanem a második feleségéé, Klaudia Felicitászé, aki 16731676 között volt a császár felesége. ${ }^{14}$

Ha az esztergomi csempék készítómúhelyét nem is sikerült pontosan meghatározni, az jól lát-

14 A párhuzamokért Harald Rosmanitznak kell köszönetet
mondanom, aki felhívta a figyelmemet ezekre a darabokra. 

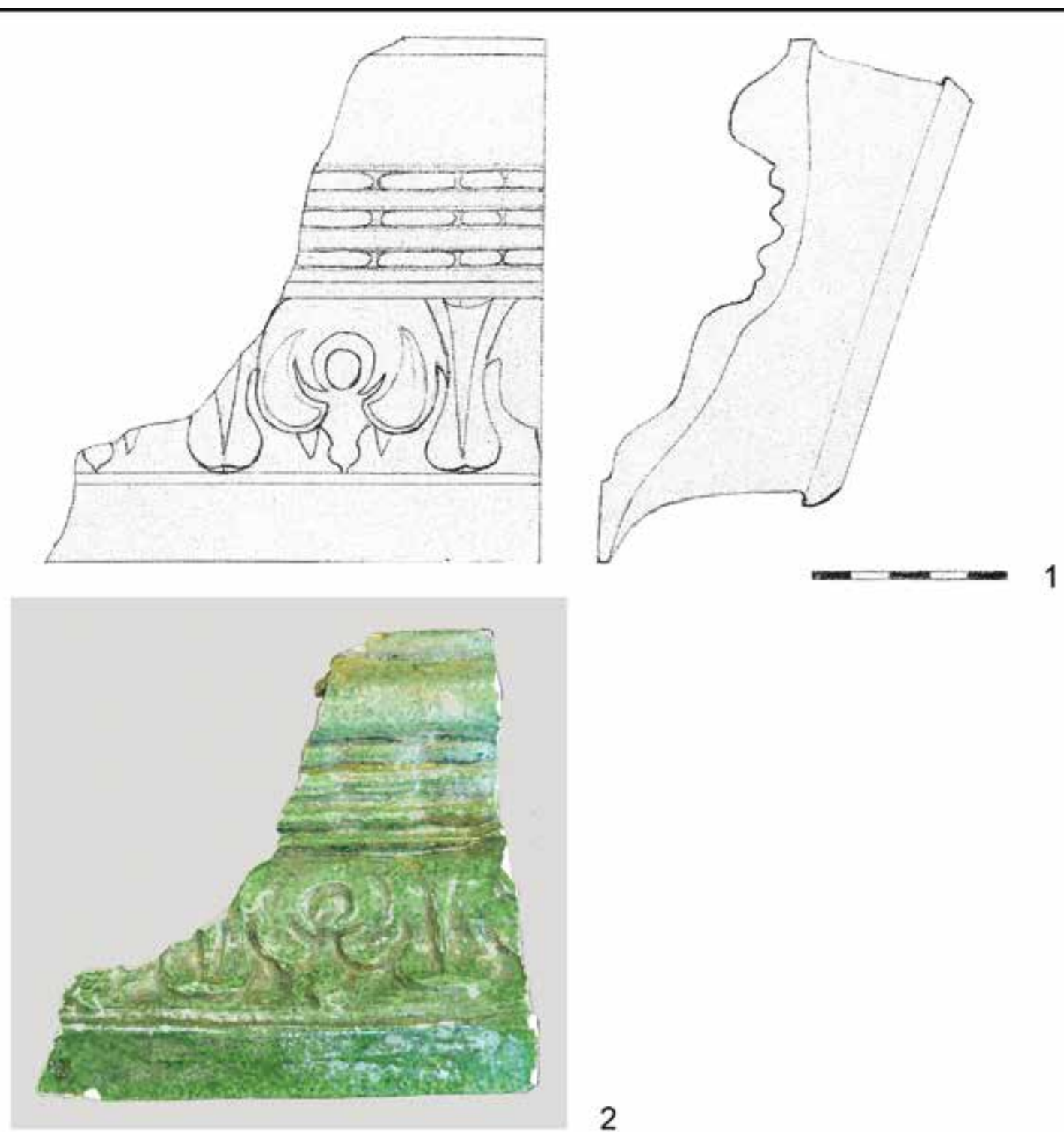

2

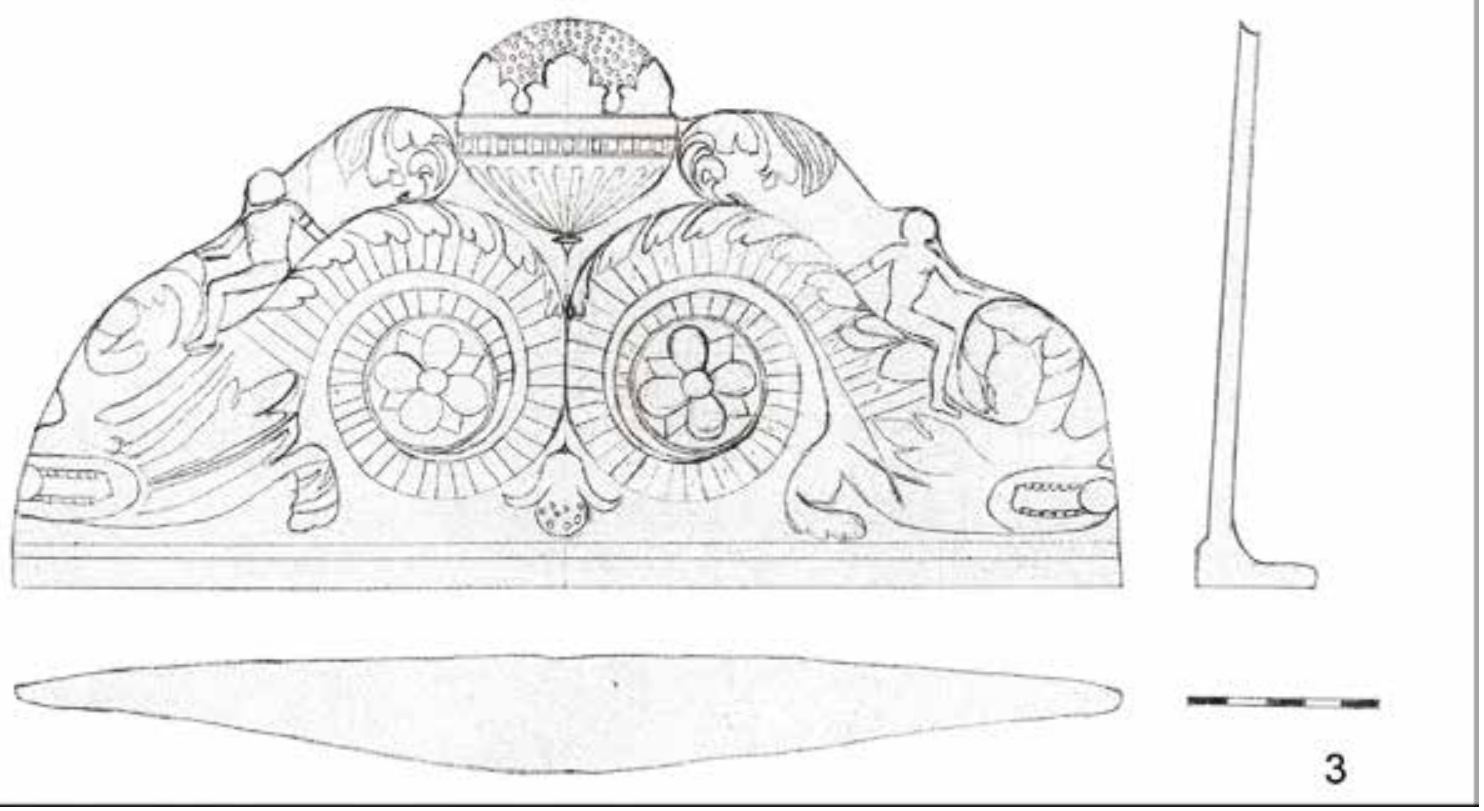

10. kép. Kályha kétfejú sassal és I. Lipót császár portréjával. 1: Középpárkány rajza és oldalnézete; 2: Középpárkány töredéke; 3: Pártalap rajza és metszete (rajz és fotó: Kocsis Edit)

Fig. 10. Ceramic stove with double-headed eagle and portrait of Emperor Leopold I. 1: Drawing and side view of the cornice above the lower stage; 2: fragment of the cornice above the lower stage; 3 : drawing and section of a crest tile (drawing and photo: Edit Kocsis) 


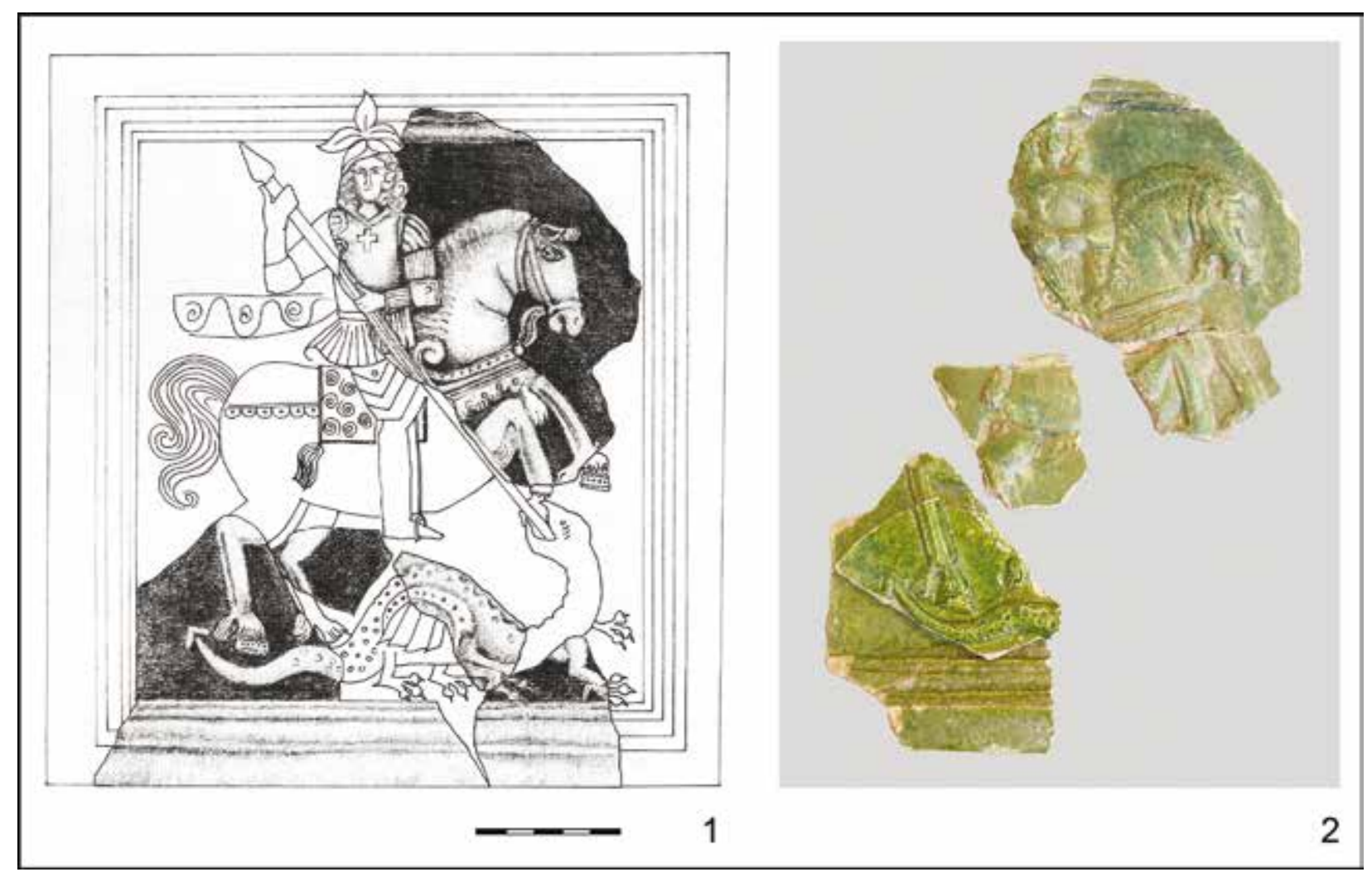

11. kép. A Szent György-alakos kályha töredékei. 1: Négyzetes csempe rajza; 2: A négyzetes csempe töredékei Szent György alakjával (rajz: Rosta Péter, fotó: Kocsis Edit)

Fig. 11. Ceramic stove depicting St. George. 1: Drawing of a square tile; 2: fragments of a square tile with the figure of St. George (drawing: Péter Rosta, photo: Edit Kocsis)

ható, hogy a csempéken fellelhető stíluselemek Németország déli területei felé mutatnak, valahonnan innen érkezhetett Esztergomba a kályha készítője.

\section{Szent Györgyöt ábrázoló kályha}

Az esztergomi várban egykor állt Szent Györgyös kályhából sajnos csak igen kevés töredék maradt fenn. Azonos negatívból származó, vagy nagyon hasonló ábrázolású töredékek azonban számos helyról elókerültek már, s ezek segítségével meg lehet kísérelni ezeknek a csempéknek a rekonstrukcióját is.

A csempék anyaga viszonylag durván, kavicsszemcsékkel is soványított, fehérre, illetve sárgásfehérre égetett cserép. Az előlapokat - engób használata nélkül - általában világos árnyalatú zöld mázzal vonták be. A máz egyes csempéken foltosra sikerült, illetve megfakult, s néhány darabon a földben ezüstösen irizálóvá vált. A csempék előlapjait textil alkalmazása nélkül préselték a negatívba, viszont számos csempe hátoldalán láthatóak a kályhásmester ujjainak sekély baráz- dái, ahogy függóleges irányban belesimította az agyagot a préselőformába. Ez a jellegzetesség néhány pártaelemen is megfigyelhetó. Egyes csempehátoldalakon erőteljesebb belenyomkodás jelei is látszanak. A négyzetes és téglalap alakú csempék tagolt keretet kaptak. Csak Szent György sisakjának tollforgója, illetve a lándzsarúd vége nyúlhatott túl a képmezőn, rá a felsó keretre (esetleg alul még a sárkány egy-két lábujja). Itt is jellemző, ahogy az előző két kétfejú sasos kályhánál is, hogy kis eltérésektől eltekintve ugyanazt a jelenetet alakították ki közel négyzetes és téglalap alakú képmezóbe szerkesztve. Ebben az esetben ezt úgy érték el, hogy a négyzetes csempéknél kisebbek lettek az ábrázolás részletformái, és oldalt több az üres felület, míg a téglalap alakú, nagyobb részletformákkal rendelkező csempéknél alul maradt több üres terület. A csempék 3,5-6 cm mély, szalagszerú hátrészt kaptak, s a hátrészek végét kifelé lekerekítve vagy inkább szögletesre formázva visszagyưrték.

Négyzetes csempék. A csempék kiszerkeszthető mérete kb. $24 \times 24 \mathrm{~cm}$, mélységük 4-6 cm. Négyöt csempéből vannak töredékek. 


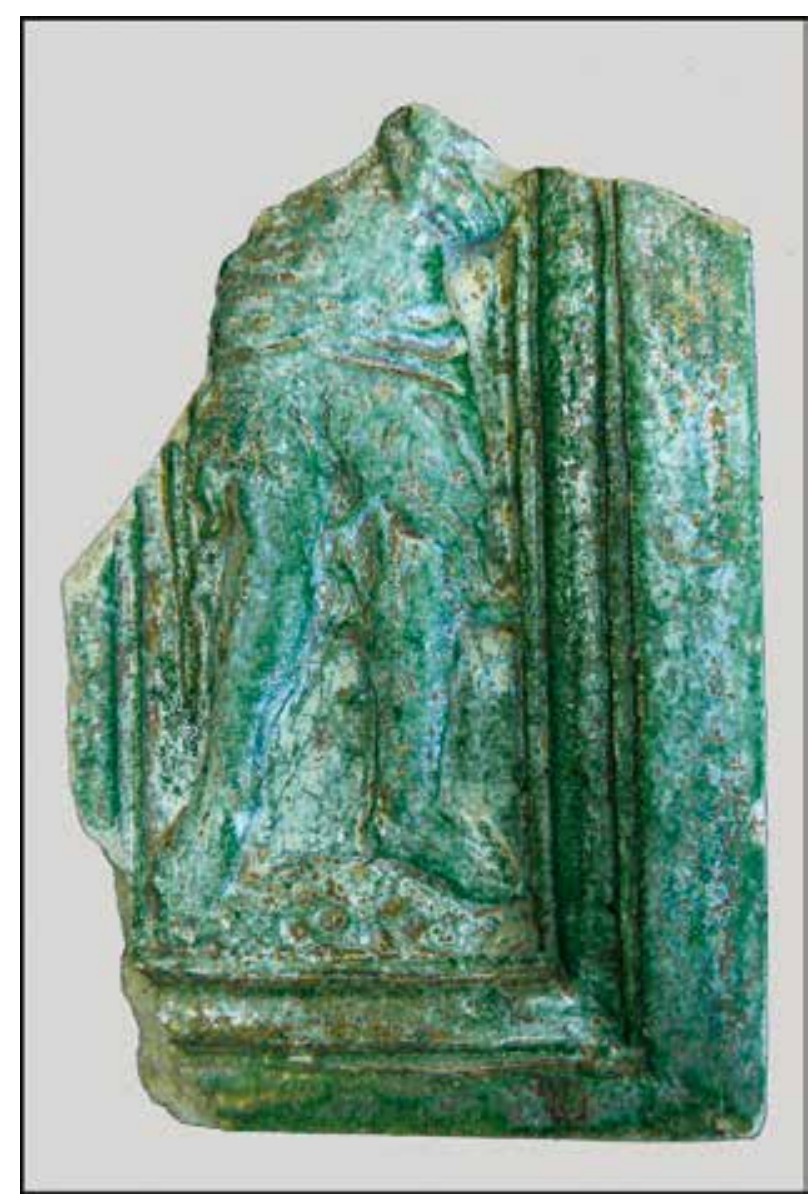

12. kép. Sarokcsempe félcsempéjének töredéke Szent Kristóf ábrázolásával a Szent György-alakos kályháról (fotó: Kocsis Edit)

Fig. 12. Fragment of the half-tile of a corner tile with the figure of St. Christopher from the ceramic stove decorated with figures of St. George (photo: Edit Kocsis)

A csempék összetett kerete kívül egy kb. $1,3 \mathrm{~cm}$ széles léctaggal indul, majd egy éles lépcső után egy kb. 0,5 cm széles hornyolattal mélyül, végül egy újabb lépcső után egy keskeny pálcatag zárja le. A képmezőben egy jobbra ágaskodó paripa látható szépen befont sörénynyel, díszes kantárral, szügy- és farhámmal. A ló hátán magas kápájú, mintás takarójú nyeregben Szent György ül, deréktól felfelé szembefordulva a nézóvel. Szent György ráncolt anyagú zekéje felett mellvértet, váll- és könyökvédő páncélt visel. A mellvérten egyenlő szárú kereszt lóg, és az alak nyaka körül mintás anyagú köpeny záródik, amelynek vége a dereka mögött hosszan fodrozódva lobog. Szent György arca bajusz és szakáll nélküli. Fején három nagy tollal ékesített sisakot visel, amely alól vállig omlanak le göndör fürtjei. A sisak tollai már a keret belsó oldalára is rányúlnak. A szent mindkét kezével egy lándzsát szorít, amelynek alsó végét a lova patái alatt elhelyezkedő, fejét visszafelé fordító sárkány szájába döfi. A sárkány testének pikkelyeit benyomott pontok érzékeltetik, hátán íves tarajok láthatók, szárnya testéhez simul, négy lábán karmos ujjak vannak, elkeskenyedő farka nyílszerúen végződik. A sárkány karmai és a lándzsa felső vége szintén kissé rányúlnak a keret belső részére. Bár a jelenet elég jól kitölti a képmezőt, az oldalkeretek mentén néhol nagyobb üres felületek is maradtak (11. kép 1-2).

Sarokcsempe, félcsempe. A sarokcsempe feltételezett magassága $24 \mathrm{~cm}$, szélesebb oldala $\mathrm{kb}$. $24,5 \mathrm{~cm}$ lehetett, keskenyebb oldala $\mathrm{kb} .12 \mathrm{~cm}$ volt. Egy csempe töredékeit ismerjük.

A csempe sarokélét a két csempe összetett keretének kissé kiszélesített léctagjai adják, amelyeket derékszögben illesztettek össze. A négyzetes csempeoldal sajnos letört. A félcsempeoldal öszszetett kerete kívül széles léctaggal indul, majd egy éles lépcső után széles hengertaggal mélyül, végül egy újabb lépcső zárja le. A $6 \mathrm{~cm}$ szélességú képmezőben egy mezítlábas alak áll a kidomborodó talajon, ruhája a combja táján cafrangokra hasadt, felemelt bal karján valamit tart. A csempe többi része nem maradt meg. Az ábrázoláson valószínúleg Szent Kristóf jelenik meg, karján a kis Jézussal (12. kép).

Téglalap alakú csempék. A csempék magassága kb. $29 \mathrm{~cm}$, szélessége $22,5-23 \mathrm{~cm}$, mélysége 3,5-6 cm. Öt-hat csempéból maradt fenn töredék.

A téglalap alakú csempék ábrázolása, az alakok beállítása csak apró részletekben tér el a négyzetes darabokétól, de mind a lovas, mind a sárkány nagyobb, mint a másik típuson. A képmező eltéró alakja miatt más helyeken közelíti meg az ábrázolás a keretet (pl. a ló fejénél, mellső lábainál), más részeken pedig nagyobb üres felületek maradnak (13. kép1, 3).

Középpárkány. Fektetett téglalap alakú, ívelt, felfelé szúkülő falú párkánycsempe, viszonylag vékony falú. Magassága kb. $12 \mathrm{~cm}$, mérhető szélessége $12 \mathrm{~cm}$, rekonstruálható szélessége $\mathrm{kb} .21 \mathrm{~cm}$, mélysége kb. $6 \mathrm{~cm}$. Egy csempe három töredéke van meg.

A párkány alsó, „S" alakban felfelé szúkülő harmadában, széles léctag és pálcatag felett lefelé fordított levélsor fut szépen tagolt, erősen cakkozott szegélyú stilizált levelekkel. A középső, függőleges falú harmadot egy vízszintes pálca választja el, ebben apró virágos, indás motívum fut, de ebból csak nagyon kevés maradt meg. A párkánycsempe felső sávja ismét kissé előre- 


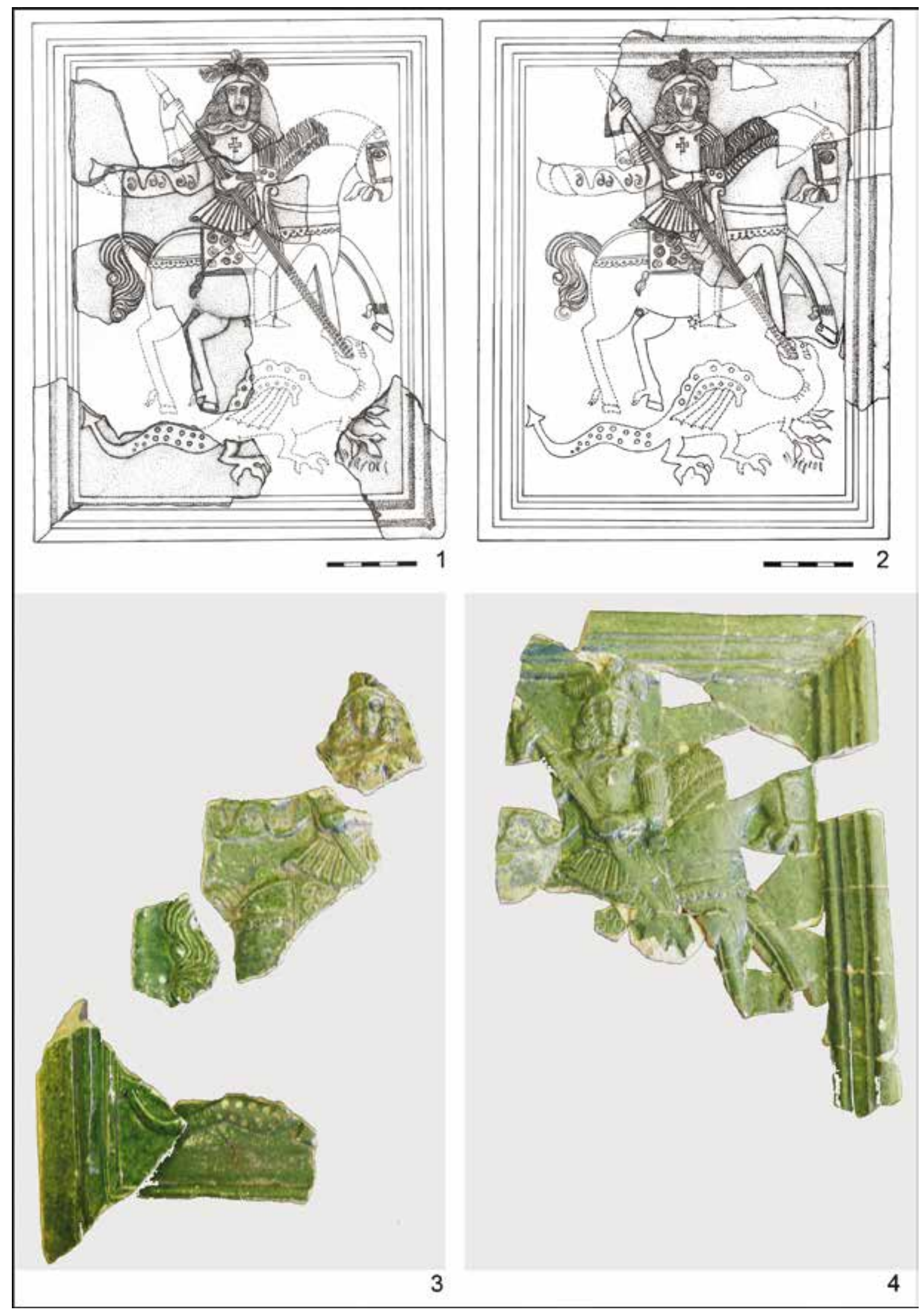

13. kép. Szent György-alakos kályhák töredékei. 1: Téglalap alakú csempe rajza az esztergomi kályháról; 2: Téglalap alakú csempe rajza a visegrádi kályháról. (Rajz: Molnár Éva); 3: Téglalap alakú csempék töredékei Esztergomból; 4: Téglalap alakú csempék töredékei Visegrádról (fotó: Kocsis Edit)

Fig. 13. Fragments of tiles with the figure of St. George. 1: Drawing of a rectangular tile from the Esztergom ceramic stove; 2: drawing of a rectangular tile from the Visegrád ceramic stove (drawing: Éva Molnár); 3: fragments of rectangular tiles from Esztergom; 4: fragments of rectangular tiles from Visegrád (photo: Edit Kocsis) 

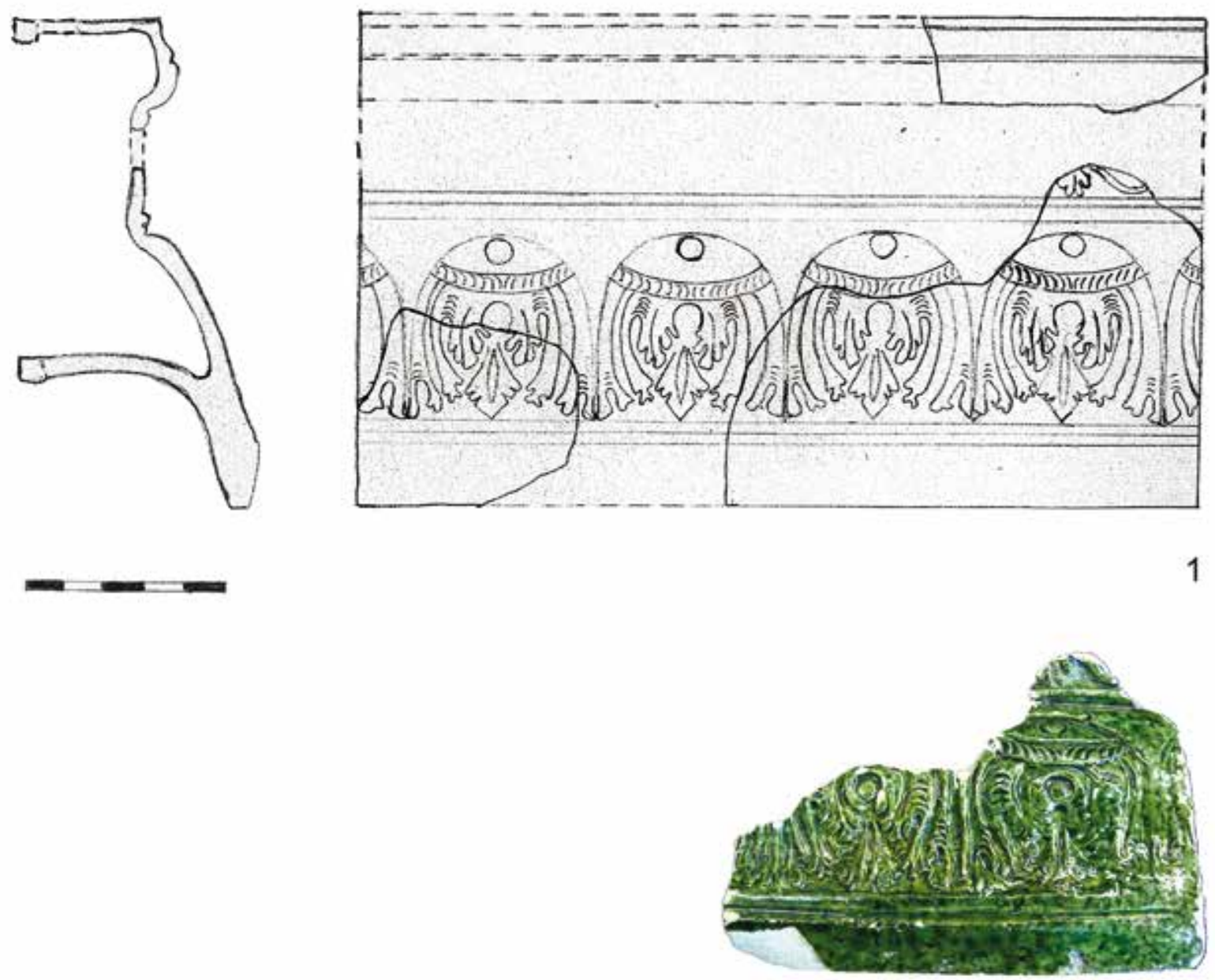

14. kép. A Szent György alakos kályha töredékei. 1: Középpárkány rajza és metszete; 2: Középpárkány töredék (rajz és fotó: Kocsis Edit)

Fig. 14. Fragments of tiles from the ceramic stove decorated with figures of St. George. 1: Drawing and section of the cornice above the lower stage; 2 : fragment of the cornice above the lower stage (drawing and photo: Edit Kocsis)

ugrik, ezt a részt egy hengertag és egy pálca tagolja (14. kép 1-2).

Koronázó párkány. Felfelé szélesedő trapéz alakú, ívelt, felfelé erősen kihajló falú párkánycsempe. A csempe magassága kb. 15,5 cm, felső szélessége 23,8 cm, alsó szélessége kb. 20 cm lehet, mélysége 5,5-10 cm. Nyolc-kilenc példányból vannak töredékek.

A felfelé szélesedő párkány alsó sávját egy lépcső és egy nagy, kiugró hengertag alkotja. A felette húzódó, függóleges állású sáv díszítését egy Vácról publikált középpárkány alapján képzelhetjük el: ${ }^{15}$ középen egy levélmaszk látható, amelyből indák kacskaringóznak kétfelé, végü-

15 SÖMJÉNI 2014, 132, 16. tábla 1-2. kön egy-egy erősen tagolt szegélyú levéllel. A levélmaszkos-indás sávot alulról és felülről is lépcsősen mélyülő, kettős gombsor fogja közre. Az ívelten kihajló, széles felső sávot plasztikus, erősen tagolt levélszélú, stilizált levélsor díszíti. Felül széles, függőleges léctag zárja le a párkányt (15. kép 1).

Párta. Egyenes alaprajzú, ívelten kivágott párta, hátul végigfutó keskeny, egyenes, két szélén lemetszett támasztólappal. Magassága kb. 16,5 cm, szélessége $26,5 \mathrm{~cm}$, mélysége $4,3 \mathrm{~cm}$. 12-14 párta töredékei maradtak meg.

A motívum széle mentén szabálytalan ívben körülvágott párta a korban igen elterjedt „delfines" párták közé tartozik. Az előlap alját egy keskeny léctag és egy lépcső adja. A középső ten- 

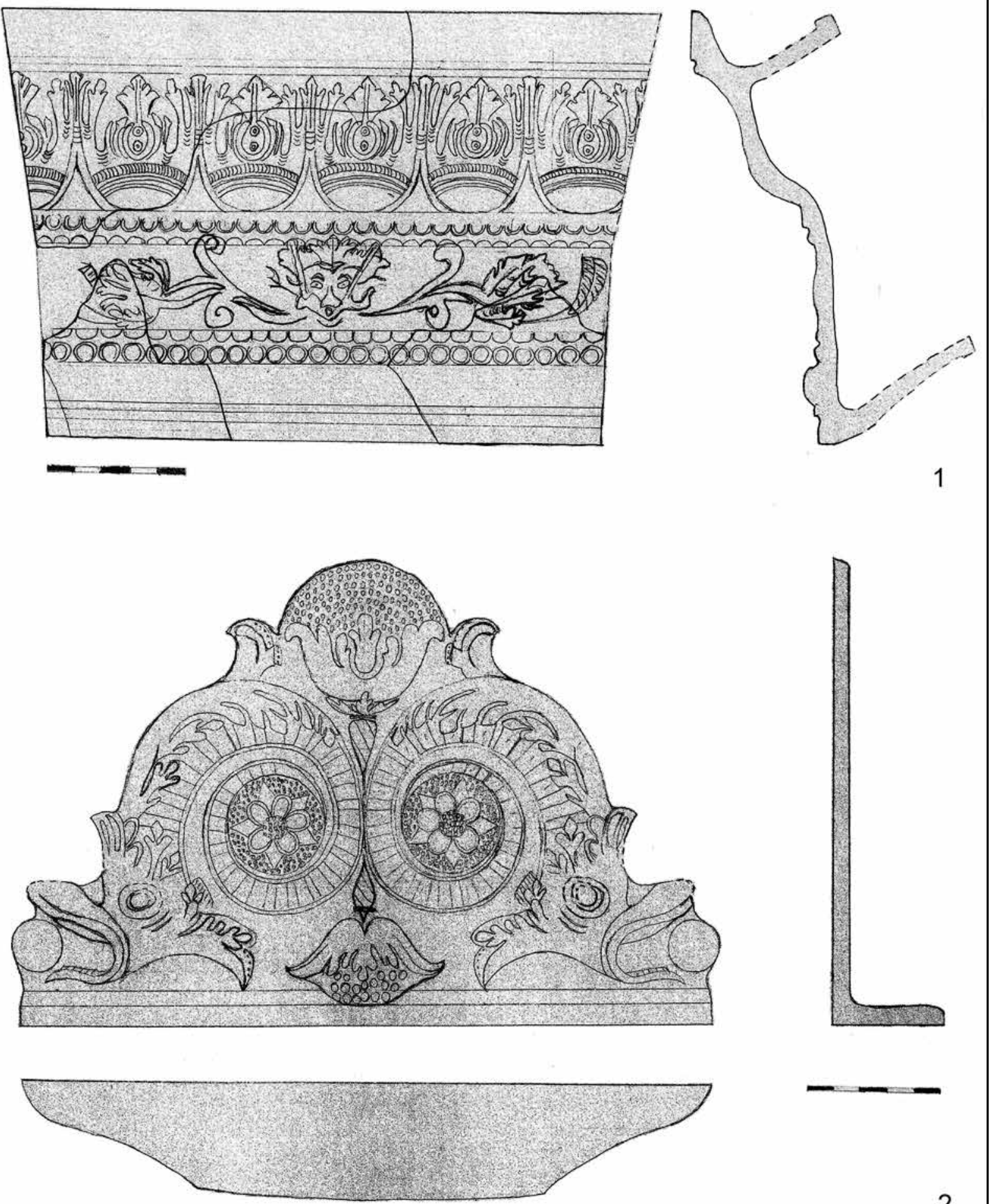

15. kép. A Szent György-alakos kályha töredékei. 1: Koronázó párkány rajza és metszete; 2: Pártalap rajza és metszete (rajz: Kocsis Edit)

Fig. 15. Fragments of tiles from the ceramic stove decorated with figures of St. George. 1: Drawing and section of the cornice above the upper stage; 2: drawing and section of a crest tile (drawing: Edit Kocsis) 
gelyre nagyjából szimmetrikus előlap két oldalán egy-egy kifelé néző delfin látható, amelyek a szájukban egy-egy gömböt tartanak. A delfinek farka felülról lefelé és befelé csavarodva tölti ki a képmezőt. Az összetekeredő delfinfarkak közepén egy-egy stilizált virág látható benyomott pontokból álló háttérrel. A delfinek hátára levelek borulnak. Középen, az érintkező delfinfarkak alól egy széles, harang alakú virág nyílik ki középen számos bibével, míg felül egy hasonló, szépen tagolt bibés virág emelkedik ki korongszerúen, így zárva le felülről a pártát (15. kép 2). A párta előlapja jóval plasztikusabb, mint az I. Lipót-portrés kályha delfines pártájáé. A párta analógiája Sümegről1 ${ }^{16}$ ismert, de Kozák Károly megjegyzése szerint Nagyvázsonyban is került elő ilyen darab.

\section{A kályha felépitése}

A Szent György-csempés kályha felépítése hasonló lehetett az előzó két kályháéhoz. Az alsó részt közel négyzetes csempék alkották - kötésben rakva, összeépített sarokcsempéket is alkalmazva. A sokszöghasáb alakú felső részt téglalap alakú csempékből rakták. A fútóberendezésnek közép-, valamint kihajló koronázó párkánya is volt, tetején ívelt kivágású párták sorakoztak. A kályha fó díszítését a Szent György és a sárkány küzdelmét ábrázoló jelenet adta, amelyet négyzetes és téglalap alakú csempéken is ábrázoltak - igen hasonló beállításban, kisebb, illetve nagyobb részletformákkal, de más szentek is helyet kaphattak rajta, például a félcsempén ábrázolt Szent Kristóf.

\section{A kályhát készítô műhely}

A Szent György és a sárkány küzdelmét megörökító ábrázolások (például freskók) már a középkor óta igen népszerúek voltak - hiszen végül is a jó és a rossz harcát, $\mathrm{s}$ a jónak a gonosz felett aratott diadalát jelenítették meg. A legendát ábrázoló legkorábbi ismert kályhacsempe a 15. század elejéról való, ${ }^{17}$ de a téma később is kedvelt volt. A szenteket, s különösen Szent Györgyöt ábrázoló csempék töretlenül népszerúek maradtak még a 17. század végén, 18. század elején is, talán nem függetlenül az Ottomán Birodalom ellen folytatott hosszú küzdelemtől, illetve a katolikus ellenreformáció szellemi hatásától.

Ebből a korszakból is számos helyról közöltek már Szent György-alakos csempetöredékeket, de sajnos mindig csak kisebb darabokat. Ez meg-

16 KoZÁK 1963, 174, 47. kép.

17 Kocsis 2006, 127, 6. ábra. nehezíti egyrészt az esztergomi töredékek összerajzolását, plasztikájuk pontos meghatározását, másrészt annak megállapítását is, hogy mely töredékek készülhettek az esztergomival azonos negatívból. Nehezen dönthető el továbbá, hogy a közölt töredékek a négyzetes vagy a téglalap alakú csempeváltozathoz tartoztak-e, így a rekonstrukció még kétségesebbé válik.

Az esztergomiakhoz hasonló Szent Györgyalakos csempedarabokat publikáltak a budai várból, ${ }^{18}$ a Tabánból, ${ }^{19}$ valamint a váci várból ${ }^{20}$ is. Emellett nagyban segítette munkámat néhány közöletlen visegrádi csempetöredék, amelyek az addigra elpusztult királyi palota kertjének északnyugati sarkából származnak, valószínúleg a korai sváb település egyik házából kerülhettek a földbe. ${ }^{21}$ Hátoldaluk kormos, tehát használták őket. A csempedarabok a négyzetes, illetve a téglalap alakú csempetípushoz tartoztak (13. kép $2,4)$.

Úgy túnik, bár a Szent György-ábrázolások beállítása szinte azonos, a részletekben mégis kisebb eltérések mutatkoznak. Az esztergomi, a visegrádi és a váci töredékeken a lónak szépen befont sörénye van, Szent György köpenye csak egy szalagban, deréktájon lobog hátra, a sárkány farka pedig alig hullámzik. A budai és tabáni töredékeken viszont a ló sörénye lobog, a köpeny két részletben hullámzik az alak mögött, a nyeregtakaró más mintájú, a sárkány farka pedig eróteljes hullámokat vet. A budai darabon továbbá a csempe bal felső sarkában a "GEO RGIVS" felirat is olvasható, ahol az első három betú után a lándzsa nyele választja ketté a nevet. Tehát a budai és tabáni darabok biztosan egy másik negatívval, másik múhely által készültek, mint az esztergomi csempék. A visegrádi és váci töredékek azonban az esztergomival azonos nyomódúcból származhatnak.

A budai csempéhez valószínúleg más csempék is kapcsolódnak. Így egy sarokcsempe félcsempéje, amelyen Szent Rókus látható ${ }^{22}$ (miközben az esztergomi kályha sarokcsempéjén Szent Kristóf szerepelt), valamint egy hasonló megformálású, kalapos férfiarcot ábrázoló csempetöre-

18 Melis 1986, 265-266, 18. kép. A csempe fotóját - valószínúleg tévedésből, egy másik, 1480 körülre keltezhető csempe helyett - közölte Ana-Maria Gruia is: GrUIA 2013, 129, 308. Cat. 23.

19 JuHÁsZ 1998, 354, 10. kép.

20 SÖMJÉNI 2014, 138. 32. tábla 2-3, 33. tábla 1-7.

21 KovÁTS-SzŐKE 2015, 46-47. Visegrádra már talán az 1680-as évek végén, de az 1690-es években biztosan érkeztek betelepülők. Nagyobb számban azonban inkább csak 1700 után telepedtek le a helységben.

22 MeLis 1986, 266-267. 
dék. ${ }^{23}$ Ez utóbbi valószínúleg egy Szent Mártont ábrázoló négyzetes csempéből származhat, analógiáját Szombathelyről közölték. ${ }^{24}$ Ezen egy bal felé lépó lovon, a nyeregben visszaforduló Szent Márton látható, amint a bal kezével megemelt köpenyét jobb kezében tartott kardjával kettéhasítja, hogy a lova hátsó lábainál kuporgó, majdnem ruhátlan koldusnak adja. A csempe részleteinek megformálása: Szent Márton arca, kalapja és ruházata, a ló sörénye, patái, a nyeregtakaró mintázata, valamint a csempe kerete mind nagyon hasonlítanak a budai és a tabáni Szent György-ös csempére, s ráadásul a csempe jobb felső sarkában itt is látható - ezúttal három sorban elhelyezve - az értelmezést segítő felirat: „S. MARTIN $\mathrm{VS}^{\prime \prime}$.

Amint láthattuk, az esztergomi kályha múhelye a Dunakanyar két másik településére, Visegrádra és Vácra is készített fútóberendezést. Érdekes, hogy Vácon az esztergomi kályha koronázó párkányának motívuma is felbukkan - ezúttal középpárkánnyá szabva -, bár a csempék publikálója szerint ez ott egy másik, kétfejú sasos csempéjü fútóberendezéshez tartozott. ${ }^{25} \mathrm{~A}$ különböző leveles párkányok, delfines párták nagyon népszerúek voltak, préselőnegatívjaik akár kereskedelmi úton is terjedhettek, s több múhely akár különböző motívumú kályhákhoz is felhasználhatta őket ekkoriban.

A Szent György-ös csempék aprólékosan kimunkált plasztikája, valamint az, hogy egyes részletek a tagolt keretre is rásimulnak, talán megengedi azt a feltételezést, hogy a múhely (múhelyek) esetleg nyugatról érkezhettek Magyarországra az ország törököktől való megtisz- títása és keresztény újratelepítése idején. Erre utal a kályhák elterjedése is, hiszen a nyugatdunántúli Szombathely kivételével elsősorban a Duna vízi útja mentén készített kályhákat mindkét múhely.

\section{Összefoglalás}

A tanulmány az esztergomi vár 1686-os visszafoglalása utáni időszak három legszebb és legjobban rekonstruálható kályháját mutatja be. Ekkoriban a várban katonaság állomásozott, s ezek a fútőberendezések valószínúleg a tisztek és a parancsnok szállását, helyiségeit fúthették. Két kályhát biztosan, s feltehetően a harmadikat is nyugatról hozatott mesterekkel készíttették el kiváló minőségben, néha Magyarországon szokatlan formai elemeket is alkalmazva. A külföldi kályhásmesterek alkalmazását Esztergom fekvése, a Dunán való jó megközelíthetósége is indokolhatja. A nyugatról jött mesterek múködése újabb lökést, inspirációt adhatott a hazai kályhásság fejlódéséhez.

A szépen kidolgozott, különleges csempékhez a vár anyagából jól ki lehetett válogatni az ezekhez a kályhákhoz tartozó párkányokat, pártákat is. Ezek közül az elemek közül a korszakból még viszonylag keveset publikáltak, pedig széles körben elterjedtek és népszerúek voltak, gyakran alkalmazták őket különböző fútóberendezéseknél. A kiegészítő elemek ismerete nélkül nem alkotható teljes kép a kályhák egykori felépítéséről, múhelykapcsolatairól.

\section{IRODALOM}

GRUIA, ANA-MARIA

2013 Religious Representations on Stove Tiles from the Medieval Kingdom of Hungary. Cluj-Napoca. IRÁSNÉ MELIS KATALIN

1986 Szent György alakos budai kályhacsempék. In: Fügedi E. (szerk.): Múvelődéstörténeti tanulmányok a magyar középkorból. Budapest, 254-268.

JUHÁSz ETELKA

1998 Cseréplovas töredéke Óbudáról (Keramikhusar). Budapest Régiségei (Budapest) 32, 353-359.

1999 Kétfejú sasos kályhacsempék Óbudáról (Ofenkacheln mit doppelten Adlerköpfen aus Óbuda). Budapest Régiségei (Budapest) 33, 361-364.

KOCSIS EDIT

2006 A visegrádi fellegvár kályhacsempe leletei. In: Buzás G. (szerk.): A visegrádi fellegvár. Visegrád Régészeti Monográfiái 6. Visegrád, 124-166.

2013 Jézus életét bemutató kályha az esztergomi várból, a XVI. század végéról. (Ofen mit Darstellungen des Lebens Jesu aus der Burg von Esztergom/Gran vom Ende des 16. Jahrhunderts) Archaeologiai Értesítő (Budapest) 138, 345-366.

\footnotetext{
23 MELIS 1986, 267.

24 P. HAJMÁsi 1991, 40, 1. kép.

5 SÖMJÉNI 2014.
} 


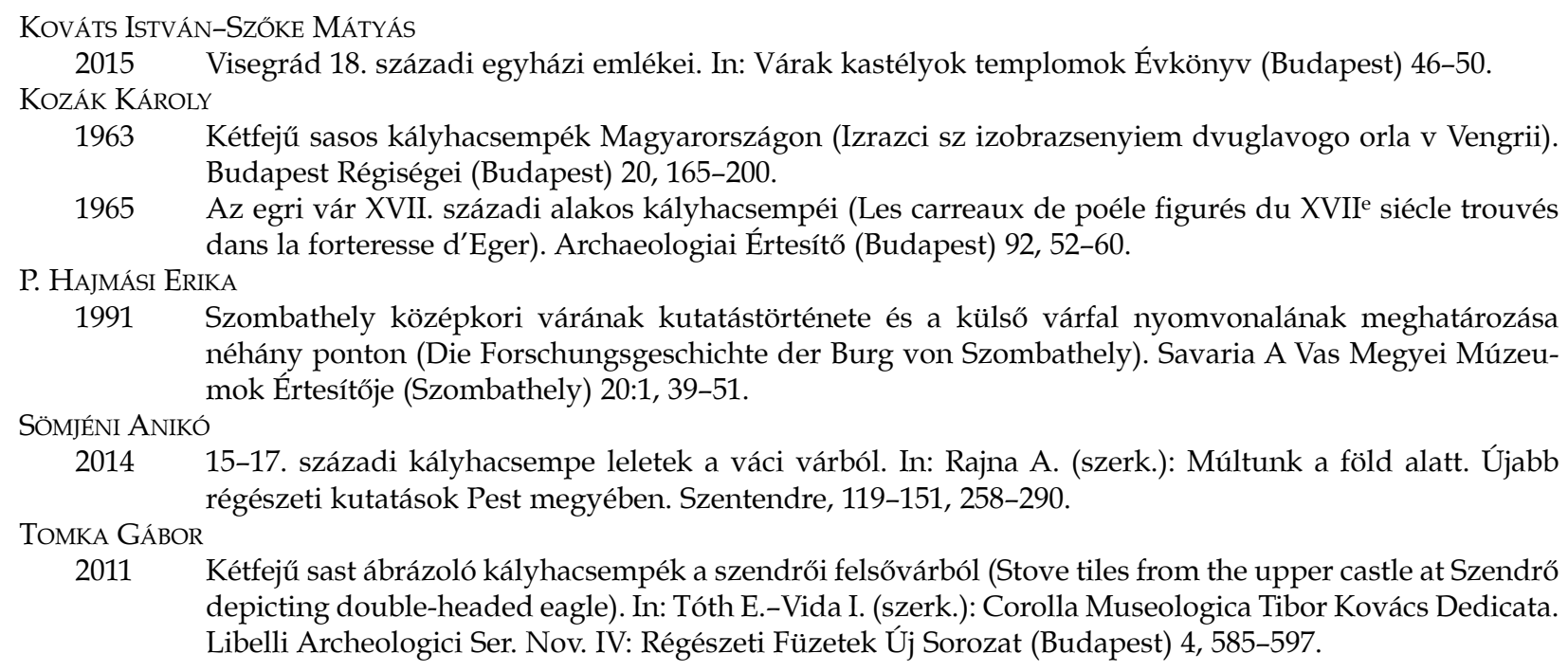

THREE CERAMIC STOVES OF ESZTERGOM CASTLE MADE AFTER 1686

\section{EDIT KoCsIS}

Described and discussed here are the three finest and best reconstructed ceramic stoves of Esztergom Castle from the period after the recapture of the castle in 1686. The stoves probably served to heat the quarters and rooms of the officers and commanders of the army troops stationed in the castle at this time.

One of the ceramic stoves is decorated with tiles whose main decorative element is the coat-of-arms of the Emperor Leopold I borne by double-headed eagles, while the other ceramic stove is made up of tiles on which the emperor's portrait can be seen on the breast of double-headed eagles. The third ceramic stove is made up of tiles portraying St. George slaying the dragon and it is possible that some tiles bore the portraits of other saints (e.g. St. Christopher). All three tiled stoves have lavishly ornamented cornices or leaf-ornamented crestings with double-headed eagles or dolphins.

Two of the ceramic stoves were quite certainly made by highly skilled craftsmen from the west and the same can be posited for the third tiled stove too. These craftsmen occasionally used formal elements that were uncommon in Hungary. The employment of foreign stove-builders was probably facilitated by the location of Esztergom and the good access to the town along the Danube. In addition to being a source of inspiration, the activity of foreign craftsmen from the west undoubtedly acted as a stimulus to the craft of ceramic stove-building in Hungary.

The cornice and crest tiles associated with the finely made, remarkable tiles of these ceramic stoves could be easily selected from among the finds. Relatively few of these elements have been published, even though they were widespread and popular, and often used during the construction of various heating installations. We can hardly form an overall picture of the structure of ceramic stoves and the connections with various workshops without a better knowledge of the complementary elements.

A cikk a Creative Commons Attribution 4.0 International License (https://creativecommons.org/licenses/by/4.0) feltételei szerint publikált Open Access közlemény, melynek szellemében a cikk bármilyen médiumban szabadon felhasználható, megosztható és újraközölhető, feltéve, hogy az eredeti szerző és a közlés helye, illetve a CC License linkje és az esetlegesen végrehajtott módosítások feltüntetésre kerülnek. (SID_1) 